\title{
B-Cells and Antibodies as Contributors to Effector Immune Responses in Tuberculosis
}

\author{
Willemijn F. Rijnink, Tom H.M. Ottenhoff and Simone A. Joosten* \\ Department of Infectious Diseases, Leiden University Medical Center, Leiden, Netherlands
}

Tuberculosis (TB), caused by Mycobacterium tuberculosis (Mtb), is still a major threat to mankind, urgently requiring improved vaccination and therapeutic strategies to reduce TB-disease burden. Most present vaccination strategies mainly aim to induce cell-mediated immunity (CMI), yet a series of independent studies has shown that B-cells and antibodies (Abs) may contribute significantly to reduce the mycobacterial burden. Although early studies using B-cell knock out animals did not support a major role for B-cells, more recent studies have provided new evidence that B-cells and Abs can contribute significantly to host defense against Mtb. B-cells and Abs exist in many different functional subsets, each equipped with unique functional properties. In this review, we will summarize current evidence on the contribution of B-cells and Abs to

OPEN ACCESS

Edited by:

Christof Geldmacher,

University of Munich, Germany

Reviewed by:

Stephen Cose,

University of London, United Kingdom

Sunil Joshi,

University of Miami, United States

${ }^{*}$ Correspondence:

Simone A. Joosten s.a.joosten@LUMC.nI

Specialty section: This article was submitted to Microbial Immunology, a section of the journal

Frontiers in Immunology

Received: 10 December 2020 Accepted: 29 January 2021

Published: 18 February 2021

Citation:

Rijnink WF, Ottenhoff THM and Joosten SA (2021) B-Cells and Antibodies as Contributors to Effector Immune Responses in Tuberculosis.

Front. Immunol. 12:640168.

doi: 10.3389/fimmu.2021.640168 immunity toward Mtb, their potential utility as biomarkers, and their functional contribution to Mtb control.

Keywords: Mycobacterium tuberculosis, tuberculosis, humoral immunity, B-cells, antibodies, biomarker

\section{INTRODUCTION}

Tuberculosis (TB), caused by Mycobacterium tuberculosis (Mtb), remains a significant health threat to mankind and is undoubtedly the most successful disease caused by a single infectious agent ever (1). TB killed $\sim 1.5$ million individuals in 2018 alone, and a total of around 1,000,000,000 people over the last 200 years $(2,3)$. In fact, approximately one-fourth to one-third of the world's population is infected with Mtb, giving rise to an estimated 10 million new cases annually (2). Mtb-infection leads to a spectrum of infectious states ranging from various levels of asymptomatic states, collectively referred to as latent tuberculosis infection (LTBI) and to a spectrum of active tuberculosis diseases (ATB), ranging from local to pulmonary to disseminating ATB $(4,5)$. About $5-10 \%$ of individuals with LTBI will progress to ATB during their lifetime; the remainder is able to contain the infection lifelong unless immunosuppressed, such as by coinfecting viruses [e.g., human immunodeficiency virus (HIV)] or iatrogenically $(1,6-8)$. These data highlight the high level of adaptation of Mtb to infect, and survive in the human host (7).

TB control is hampered by the lack of an effective vaccine: the efficacy of the only available vaccine, Mycobacterium bovis Bacillus Calmette-Guérin (BCG), ranges from 0 to $80 \%$ (9). A much better understanding of the (protective) immune response to Mtb, the mechanisms by which Mtb manipulates the host response and the identification of robust correlates of protection are all urgently needed to combat this deadly infection.

Large scale, unbiased approaches using advanced -omics technologies analyzing blood samples have been performed over the last decade and identified biomarkers associated with the different disease stages of TB, i.e., which could differentiate LTBI from ATB. In addition, biomarkers for the 
risk of progression from LTBI toward ATB were uncovered in several large prospective studies $(8,10-15)$. A frequently appearing transcriptional biomarker which was often a component of signatures able to distinguish ATB from LTBI was FCGR1A, a gene encoding the activating highaffinity crystallizable fragment $(\mathrm{Fc})$ gamma receptor I ( Fc $\gamma \mathrm{RI}$; CD64) (15-22). Fc-Receptors (FcRs) potentially can engage antibodies (Abs) that have opsonized Mtb, and thereby impact mycobacterial survival. Furthermore, in many transcriptomic studies also components of the complement pathway were identified, predominantly transcript-markers from the classical pathway, that were differentially expressed in the blood of ATB compared to LTBI: in particular Complement component1qB $(C 1 Q B)$ and $C 1 Q C$ were higher expressed, and in support of this, serum C1q-protein was found to be a diagnostic biomarker for ATB $(18,20,23-25)$. More recently, it was reported that the combined measurement of serum $\mathrm{C} 1 \mathrm{q}$ and whole blood type-1 interferon (IFN) signature might help improving the diagnosis of ATB (26). Together, these studies hint to the potential influence of humoral immune components in TB, including innate and possibly also adaptive humoral immunity. Indeed, in support of this initial data, B-cells and Abs were later proposed to correlate with protective immunity against $\mathrm{TB}(4,6,27-31)$. This review will explore the role and possible utility of B-cells and Abs as biomarkers of immune protection against Mtb.

As a facultative intracellular bacterium that residues primarily in lung alveolar macrophages, the vast majority of TB research efforts has traditionally focused on understanding cell-mediated immunity (CMI) [reviewed in Cooper (32), Lin and Flynn (33), Ottenhoff (34), North and Jung (35)]. By contrast, the role of B-cell- and antibody-mediated immunity (AMI) in TB has remained understudied for decades. This was due to the historical dogma, established in the early twentieth century, that postulated that host defense against intracellular pathogens is mediated by

\footnotetext{
Abbreviations: Ab, antibodies; Acr, $\alpha$-crystallin; ADCC, antibody-dependent cell-mediated cytotoxicity; ADCP, antibody-dependent cellular phagocytosis; Ag, antigen; AM, arabinomannan; AMI, antibody-mediated immunity; AP, activator protein; APC, antigen-presenting cell; ATB, active tuberculosis disease; BAL, bronchoalveolar lavage; BCF, B-cell follicle; BCG, Bacillus Calmette-Guérin; Breg, regulatory B-cell; C1q, Complement component 1q; $\mathrm{Ca}^{2+}$, calcium; CFP$10,10 \mathrm{kDa}$ culture filtrate protein; CMI, cell-mediated immunity; CVID, common variable immunodeficiency; CXCL, CXC chemokine ligand; CXCR, CXC chemokine receptor; ESAT-6, early secreted Ag of $6 \mathrm{kDa}$; Fab, Ag-binding fragment; FASL, Fas ligand; Fc, crystallizable fragment; Fc $\gamma$ RI, Fc gamma receptor I; FcR, Fc receptor; GC, germinal center; HBHA, heparin-binding hemagglutinin adhesin; HIV, human immunodeficiency virus; iBALT, inducible bronchusassociated lymphoid tissue; IFN, interferon; Ig, immunoglobulin; IGRA, IFN- $\gamma$ release assay; iNOS, inducible nitric oxide synthase; IRF, interferon regulatory factor; IVIg, intravenous immunoglobulin; LAM, lipoarabinomannan; LAMP-1, lysosomal-associated membrane protein 1; LTBI, latent tuberculosis infection; $\mathrm{mAb}$, monoclonal antibody; ManLAM, mannose-capped lipoarabinomannan; Mtb, Mycobacterium tuberculosis; MVA85A, Ankara virus modified to express Ag85A; NF-кB, nuclear factor kappa-light-chain-enhancer of activated B-cells; NHP, non-human primate; NK, natural killer; pIgR, polymeric immunoglobulin receptor; PIM, phosphatidyl-myo-inositol mannoside; PPD, protein purified derivative; PS, polysaccharide; QFN, QuantiFERON-TB Gold In-Tube test; QFT, QuantiferonTB Gold; SCID, severe combined immunodeficient; sIgA, secretory IgA; TB, tuberculosis; Th, T helper; TLR, Toll-like receptor; TNF, tumor necrosis factor; TRIM21, FcR tripartite motif-containing protein 21; TST, tuberculin skin test; WT, wild type; XLA, X-linked agammaglobulinemia.
}

CMI, whereas the response to extracellular pathogens is mediated by Abs produced from B-cells (4, 7, 36-39). B-cells, however, do not only produce Abs, they are also competent antigen (Ag)-presenting cells (APCs), and produce a wide range of cytokines. All of these B-cell properties can influence the function of a broad range of other immune cells, including T-cells, macrophages, neutrophils and dendritic cells in their response to pathogens $(7,37)$. AMI combats extracellular pathogens via various mechanisms, such as viral and toxin neutralization (e.g., neutralizing extracellular microorganisms or their products), opsonization (e.g., facilitating bacterial phagocytic uptake by, and recruitment of neutrophils) and complement activation, which can further enhance opsonization and bacterial lysis, but also phagocytosis through complement receptors $(40,41)$. The effector mechanisms used by specific Abs to remove pathogens is dependent on a variety of features, which include Ag specificity, Ab isotype and subclass, as well as post-translational modifications, like glycosylation (42) (Figure 1).

As Mtb is an intracellular pathogen, Mtb-specific Abs were classically considered to be unable to gain access to phagosomal Mtb bacilli (43). However, several experimental studies in recent decades have shown that B-cells/AMI can contribute to protective immunity, or at least considerably influence host defense, against pathogens with a preferred intracellular niche, such as Chlamydia trachomatis $(44,45)$, Salmonellae (46-48), Ehrlichia chaffeensis (49), Leishmania major (50), Leishmania amazonensis (51), Leishmania panamensis (52), Cryptococcus neoformans (53, 54), Coxiella burnetii (55), Trypanosoma cruzi (56), Francisella tularensis (57), and Plasmodium chabaudi chabaudi (58). Similarly, proof that B-cells and certain Abs can modulate $\mathrm{TB}$ disease is gradually accumulating as discussed in this review and previously elsewhere (7, 29-31, 37, 59-64). The evidence for a contribution of B-cells and antibodies to Mtb clearances varies greatly, which variability may be partly the result of genetic or environmental differences in study populations, which are in particular present in the diverse populations studied in the context of $\mathrm{TB}$, which supports the need of more global assessment of effector responses, including humoral responses. Moreover, although studies in experimental animals have been highly informative, the immune system, including the B-cell compartment, differs amongst species and cannot be completely extrapolated to human infectious diseases. Therefore, a more comprehensive unbiased approach to investigate the functional involvement of cellular immunity, B-cells and humoral immunity, their relative importance, as well as their interconnections in protective immunity against Mtb could enhance our understanding of host defense in Mtb and ultimately might translate into the development of more efficacious therapeutic and preventive tools.

\section{THE ROLE OF B-CELLS IN HOST-DEFENSE AGAINST MTB}

The contribution of B-cells and Abs to immunity against Mtb has been investigated for over 100 years, but results have been inconsistent and sometimes even contradictory $(64,65)$. A 


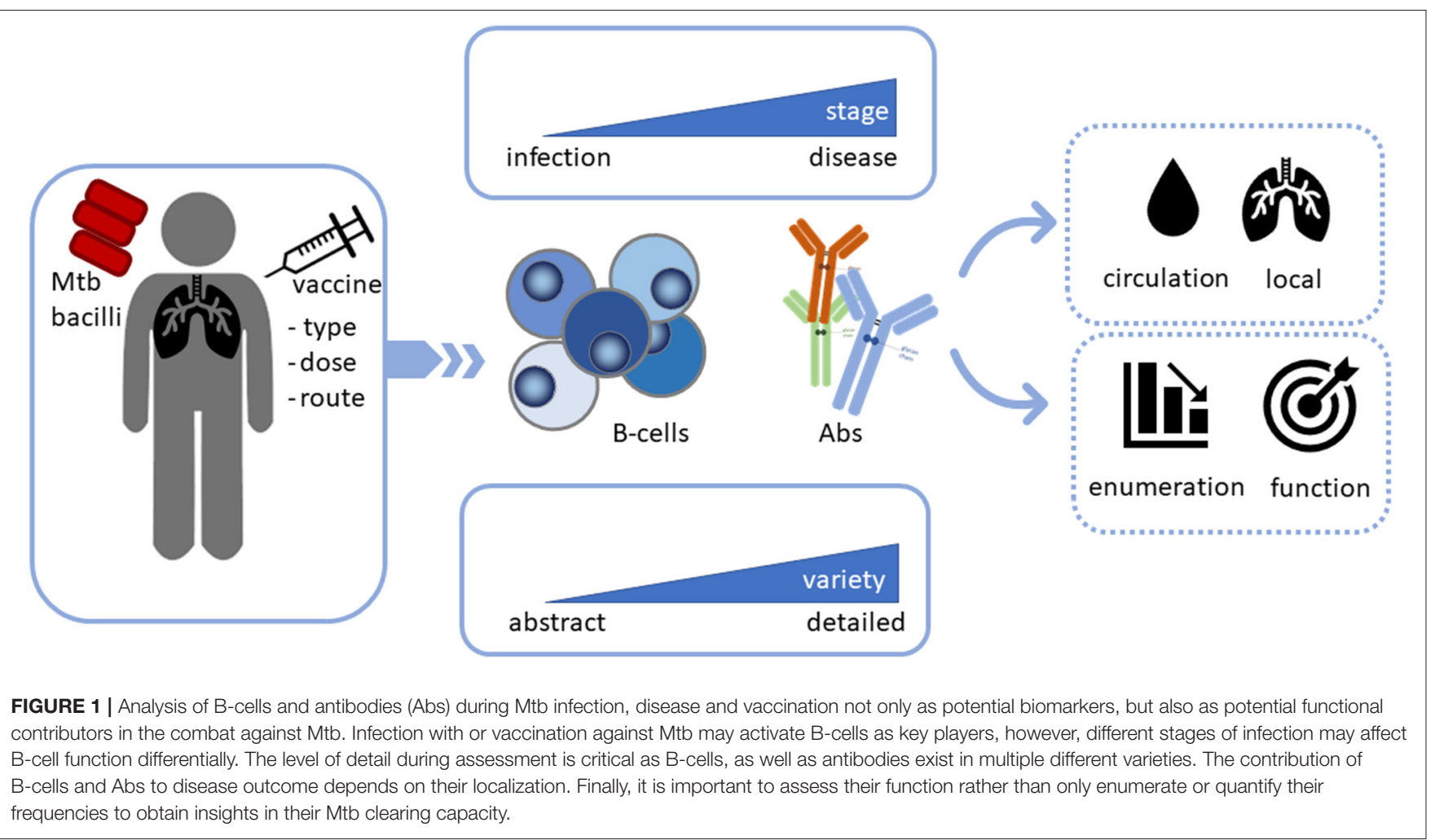

plethora of human and animal studies has suggested though that B-cells and Abs contribute to resolution of TB (Figure 1).

In the past two decades, several studies have reanalyzed the role -protective, neutral or detrimental- of B-cells in TB, using various experimental murine TB-models, including B-cell deficient mice. Some of the results were not in full agreement or even contradictory, with reports showing reduced immunity, delayed dissemination, or even marginal or no detectable effects following genetic deletion (66-73). Both short-term (72) and long-term $(70,71)$ aerosol infections using virulent Mtb-strain H37Rv (72), Erdman strains (70) or clinical isolate CDC 1551 (71) [with inocula of $\sim 50-100(70,71)$ or $100-1,000$ (72) viable bacilli per lung], showed no detectable differences in lung bacterial loads in wild type (WT) vs. B-cell deficient mice. Conversely, studies administering a higher intravenous (73) or intrabronchial (69) dose of Mtb, $10^{6} \mathrm{Mtb} \mathrm{H} 37 \mathrm{Rv}$ (73) or four to eight colony forming units of Mtb Erdman (69), respectively, reported an augmented susceptibility to infection, as measured by tissue bacterial burden, in B-cell deficient compared to control mice. Adoptive transfer of B-cells reversed the increased lung immunopathology in B-cell knock-out mice, demonstrating a contribution of B-cells to the control of Mtb (69). In concordance, a high-dose aerosol infection murine TBmodel reported exuberated pulmonary pathology with enhanced pulmonal neutrophil recruitment in B-cell deficient mice (67). This study additionally showed that subcutaneous BCGvaccination elicited an impaired Th1 response in the absence of B-cells. In another vaccination study, adoptive B-cell transfer did not augment anti-TB protection in B-cell knockout mice, but protection required the presence of T-cells (66). However, here the human adenovirus-based vaccine was a powerful T-cell activator that might have acted independently of B-cells.

Extending beyond mouse models, in a $\mathrm{CD} 20^{+} \mathrm{B}$-cell depleted acute Mtb-infected cynomolgus macaque model, analysis of individual lesions revealed that some, but not all, lesions contained an increased mycobacterial burden and lower levels of inflammation compared to non-depleted animals (74). Thus, despite studies reporting a detrimental or neutral effect of B-cells on anti-TB immunity, there is also increasing evidence for B-cells in promoting optimal protection against $\mathrm{Mtb}$. The contradictory data from studies in B-cell deficient mice may have resulted from differences in the dose and route of delivery, the phase of infection, the mycobacterial strain and the mice strains used (67-72) as was also previously discussed (7).

\section{THE ROLE OF Abs IN THE HOST DEFENSE AGAINST MTB}

\section{Passive Transfer Studies}

A major breakthrough in the immunology and treatment of infectious diseases was the discovery of serum therapy in the mid-1890s $(65,75)$. A comprehensive account of these early and later studies (from 1880 until mid-1990s) and their limitations was reviewed by Glatman-Freedman and Casadevall (65). Three passive polyclonal immunoglobulin (Ig)G or serum transfer studies provided support for the protective nature of immune serum against Mtb (76-78). Serum therapy with polyclonal Abs against Mtb effectively protected against disease reactivation in Mtb-infected severe combined immunodeficient (SCID) mice after partial treatment with anti-tuberculous drugs (77). In 
addition, human high-dose intravenous immunoglobulin (IVIg) administration to Mtb-infected C57BL/6, but not nude mice, induced a substantial decline in mycobacterial numbers in the lungs and spleen (78). Sera from some LTBI or highly exposed, but uninfected, healthcare-workers contained protective Abs as shown by serum transfer into mice challenged with aerosol Mtb (76). Thus, in spite of the mixed results obtained in the early passive transfer studies, newer reports underscore the protective capacity of some, but not all, sera and Abs against Mtb. These results call for detailed characterization of the precise properties of polyclonal $\mathrm{Ab}$ responses capable of reducing mycobacterial burden.

\section{Monoclonal Antibody Therapeutic Studies}

The development of the hybridoma technology in 1975 provided a tool to overcome the limitations of passive serum transfer with polyclonal Abs, through the production of monoclonal antibodies (mAbs). At the end of the 1990s, one of the first studies that generated mAbs against Mtb evaluated the capacity of three mAbs to influence the course of infection in mice that mainly displayed progressive TB disease (79). Only one mouse mAb, an IgG3 mAb (clone 9d8) specific for the mycobacterial capsular polysaccharide arabinomannan (AM), was able to prolong survival after Mtb challenge via improved tuberculous granulomatous containment of the pathogen (80). Since this pioneering study, several independent studies exploiting mAbs, including different isotypes, IgA (8188), IgG1 (89), IgG2b (90), and IgG3 (91), against diverse mycobacterial Ags, such as $\alpha$-crystallin (Acr) (81, 83-88), MPB83 (90), lipoarabinomannan (LAM) (89), and heparin-binding hemagglutinin adhesin (HBHA) (91), have additionally reported protective potential. Efficacy was evaluated by prolonged survival time $(89,90)$, reduced dissemination (91), diminished tissue pathology $(83,85,87,90)$ and decreased mycobacterial burden as assessed through colony-forming units (82-89). The antibodyisotype is critical for effector function as switching the constant region of the IgA monoclonal 2E9 to Acr abrogated the protective efficacy (81). Interestingly, adoptive transfer of $\operatorname{IgA}$ combined with IFN- $\gamma$ had a strong effect on the bacterial load in a multi-drug resistant $\mathrm{Mtb}$ model in mice. Further passive transfer studies of mAbs preferably side-by-side, and including a BCG-immunized control group for referencing, are required to compare and validate the effects of $\mathrm{Ab}$-mediated protection against the tubercle bacillus. Moreover, the development of human or humanized mAbs toward key Mtb epitopes might further define protective humoral responses with significant preventive and/or therapeutic potential.

\section{Human Observational Studies}

In addition to passive transfer and $\mathrm{mAb}$ therapeutic studies, insights were also obtained from human observational studies. A meta-analytic study in China showed that patients with Xlinked agammaglobulinemia (XLA), a deficiency that results in the absence of B-cells and serum Igs, did not have an elevated risk to developing ATB (92). Likewise, patients with common variable immunodeficiency (CVID) did not have increased susceptibility to TB (93). However, these observations could be confounded by IVIg therapy given to most patients $(92,93)$. Moreover, an argument often used to argue against a significant role of Abs in the control of Mtb is that humans treated with Rituximab, a B-cell depleting anti-CD20 $\mathrm{mAb}$, did not have an increased risk of reactivating TB $(94,95)$. Counter arguments, however, include that Rituximab has a limited depleting effect on CD20negative $\mathrm{Ab}$ secreting plasma cells and is also not able to modify pre-existing Ab levels, thus not excluding that the absence of increased susceptibility seen in these patients might be the result of remaining Abs $(94,95)$. Moreover, Rituximab is mostly used in developed countries where TB-incidence and thus the risk of acquiring Mtb-infection is very low. In addition, patients about to start this treatment are routinely screened for LTBI and will first receive preventive antibiotic treatment before initiating antiCD20 therapy. Hence, the argumentation that Rituximab does not induce an elevated risk on acquiring TB is not convincing.

While the first two studies described above $(92,93)$ provide an observational analysis in populations characterized by the absence of Abs, other studies have investigated the potential protective roles for $\mathrm{Abs}$ in $\mathrm{Mtb}$ containment more directly. Costello et al. reported that children from the United Kingdom and Southeast Asia with disseminated ATB disease had lower LAM-specific IgG serum-titers in comparison to individuals with localized ATB lesions (96). In agreement, the decrease in LAM IgG-titers from placentally transferred maternal IgGs until increased production of infant IgGs correlated with the peak incidence of disseminated ATB (96-98). Similarly, the absence of Abs binding to the mycobacterial $38 \mathrm{kDa} \mathrm{Ag}$ correlated with disseminated TB in children and TB-meningitis in adults (99). In addition, other serological studies have also found lower $\mathrm{Ab}$ serum-titers in both children and adults with extrapulmonary, active and/or disseminated TB (100-105). These human observational findings implicate that some Abs specific for particular Ags could contribute to Mtb control although causality cannot be established.

\section{THE MECHANISTIC ROLE OF B-CELLS IN TB}

Intriguingly, B-cells and Abs are not only detected in the circulation, but are also hallmarks of TB-associated granulomas, the highly organized structures formed in the lung to contain the bacilli. In particular, B-cells in the tuberculous lung have the ability to form aggregates that display features of germinal centers (GCs), bona fide organizational marks of secondary lymphoid tissues.

\section{B-Cell Organization in Ectopic Germinal Center-Like Structures in Tuberculous Granuloma in the Lung \\ Structural Organization of Granulomas in Tuberculous Lungs}

B-cells are components of the granulomatous lesions in the lungs of Mtb-infected mice $(69,106-111)$, non-human primates (NHPs) (112), and ATB patients (106, 110, 113, 114). A classical TB-granuloma contains a central region, which usually 
comprises Mtb-infected macrophages and can be infiltrated with neutrophils; can develop into necrotic with caseous cellular debris, or alternatively form mineralized lesions (7). Surrounding this necrotic center is a layer of foamy and epithelioid macrophages interspersed with Langhans giant-cells, which in turn is surrounded by an outer layer of lymphocytes scattered with macrophages $(115,116)$. At the periphery, B-cells form highly organized structures resembling B-cell follicles of secondary lymphoid organs, which are called tertiary lymphoid organs, ectopic lymphoid follicles or, if formed in the lung, inducible bronchus-associated lymphoid tissue (iBALT) (61, 117). These lesional B-cell aggregates are the predominant site of immune proliferation in the lungs of pulmonary ATB patients (114). Furthermore, immunohistochemical and flow cytometric characterization demonstrated the presence of peanut agglutinin and GL7 (two GC markers) expressing B-cells, $\mathrm{CD} 8^{+}$macrophages, central CD $21^{+}$follicular dendritic cells, CXCR5 (CXC chemokine receptor 5) ${ }^{+}$inducible co-stimulator ${ }^{+}$ $\mathrm{CD}^{+}{ }^{+} \mathrm{T}$-cells (e.g., classical $\mathrm{T}$ follicular helper cell) and tissue expression of CXCL13 (CXC-chemokine-ligand-13) in these TBectopic aggregates $(69,106)$. Together, this indicates that Bcell follicles (BCFs) in the proximity of TB-granulomas are ectopic GCs at the cellular, molecular and structural level (117, 118) and are therefore, presumably, the product of lymphoid neogenesis, a highly complex process that occurs during chronic inflammation where GC-like structures are formed ectopically in non-lymphoid tissues [reviewed in Pitzalis et al. (118), Aloisi and Pujol-Borrell (119)].

\section{Role of Ectopic B-Cell Follicles in Granulomas During Mtb-Infection}

The impact of ectopic BCFs on the course of Mtb-infection is unclear $(115,117)$. Kondratieva et al. reported that an abolished lung granulomatous architecture had no effect on severity of Mtb-infection in mice (120). Likewise, Slight et al. claimed that BCF-formation does not control tubercle bacillary growth, but that formation of these follicles is merely a result of correct $\mathrm{CXCR} 5^{+} \mathrm{CD} 4^{+} \mathrm{T}$-cell localization within the lung-parenchyma (106). On the other hand, Maglione et al. have shown that B-cell deficient mice, lacking BCFs in the lungs, have abnormal granulomatous responses correlating with augmented pulmonary pathology and suboptimal bacterial control (69). Moreover, during Mtbinfection $\mathrm{CXCR}^{+} \mathrm{CD} 4^{+}$T-cells accumulated within BCFs and locally produced proinflammatory cytokines required for effective macrophage activation and optimal bacterial control (106). Yet, in disordered BCFs associated with irregular $\mathrm{CXCR}^{+}{ }^{+} \mathrm{CD} 4^{+}$T-cell localization there was no protection against Mtb indicating a protective rather than deleterious role of organized BCFs $(106,110)$. In agreement, lung BCF formation in ATB-patients correlated with containment of lung Mtbinfection (121). In a murine TB-model, the presence of ectopic $\mathrm{B}$-cell aggregates was associated with granuloma formation and prevention of Mtb dissemination (108). Mtb and host-specific triggers that engender protective vs. pathological outcomes for BCFs are just starting to be elucidated, but probably include Ag type, type and duration of the response induced, as well as the type of Ig-subclasses involved (117, 122). Likely Mtb factors are directly guiding the organization of the granulomas and their associated BCFs (115). Collectively, this suggests a potentially protective role for ectopic pulmonary B-cell follicles during Mtb-infection.

\section{B-Cell Phenotypes and Frequencies During Mtb-Infection}

The functional role of B-cells has mostly been investigated by assessing total B-cells, however, B-cells exist in multiple flavors, each with unique properties and contributions to the host immune response. Detailed assessment of these different roles may provide an additional level of depth in the understanding of B-cell function during TB (Figure 2A).

Enumeration of B-cells during clinical $\mathrm{TB}$ has yielded contradictory results $(116,123-127)$. Significantly decreased Bcell frequencies were detected in the peripheral blood of ATB $(116,123-125)$ or LTBI (124) individuals compared to healthy controls. Others reported unaltered $(124,127)$, or even increased (126) B-cell frequencies in the blood of ATB. These conflicting data are likely the result from differences between study designs and groups of patients enrolled, varying by age, gender, ethnicity, form and severity of TB disease (61).

\section{B-Cell Subsets During Mtb-Infection}

Only few studies have assessed B-cell subset frequencies and relative changes during Mtb-infection (60, 116, 128133). Patients with ATB and LTBI had, in comparison to healthy controls, elevated circulating populations of atypical $\left(\mathrm{CD} 21^{-} \mathrm{CD}_{2} 7^{-}\right.$or $\left.\mathrm{IgD}^{-} \mathrm{CD}_{27}^{-}\right)$and activated $\left(\mathrm{IgD}^{-} \mathrm{CD} 27^{+}\right)$ B-cells, whilst the population of naïve $\left(\mathrm{IgD}^{+} \mathrm{CD} 27^{-}\right) \mathrm{B}$-cells was reduced in both patient groups (116). Atypical B-cells were not only increased in frequency, but where also functionally impaired with reduced proliferation, cytokine and $\mathrm{Ab}$ production. Upon successful antibiotic treatment, B-cell numbers and function were restored $(116,134)$. These frequency differences were confirmed in another study involving patients with ATB, other lung diseases, and following ATB-treatment (129). The circulating proportion of non-class switched marginal zone $\left(\mathrm{CD} 19^{+} \mathrm{IgM}^{+} \mathrm{CD} 27^{+} \mathrm{CD}_{23}^{-}\right)$and class-switched mature $\left(\mathrm{CD} 19^{+} \mathrm{IgM}^{-}\right)$B-cells was significantly lower in ATB-patients compared to other lung diseases, suggesting that Mtb-infection suppresses and/or exhausts B-cell effector functions, comparable to what has been observed in HIV-positive people (135). In contrast, memory B-cells $\left(\mathrm{CD} 19^{+} \mathrm{IgM}^{-/+} \mathrm{CD} 27^{++}\right)$, plasmablasts $\left(\mathrm{CD}_{19}{ }^{+} \mathrm{IgM}^{-/+} \mathrm{CD} 138^{+} \mathrm{CD} 27^{+}\right)$, memoryplasmablasts $\left(\mathrm{CD}_{1}{ }^{+} \mathrm{IgM}^{-} \mathrm{CD} 138^{+} \mathrm{CD} 27^{++}\right)$and circulating marginal zone $\left(\mathrm{CD} 19^{+} \mathrm{CD} 27^{+} \mathrm{CD} 23^{-}\right)$B-cells were significantly increased at diagnosis compared to post-treatment, suggesting their potential utility as TB-treatment response biomarkers (129). A study comparing multi-drug resistant-TB patients with healthy controls revealed decreased rates of non-class switched memory $\left(\mathrm{IgD}^{+} \mathrm{CD} 27^{+}\right)$B-cells and circulating plasma cells $\left(\mathrm{CD} 19^{\mathrm{dim}} \mathrm{IgD}^{-} \mathrm{CD} 38^{+++} \mathrm{CD} 27^{++}\right)$, with increased numbers of circulating type- 1 transitional $\left(\mathrm{IgD}^{+} \mathrm{CD} 38^{++}\right), \mathrm{CD}^{+} 9^{+}$and Toll-like receptor 9 (TLR9) ${ }^{+}$B-cells in the peripheral blood of multi-drug resistant-TB patients (131). Another study reported 

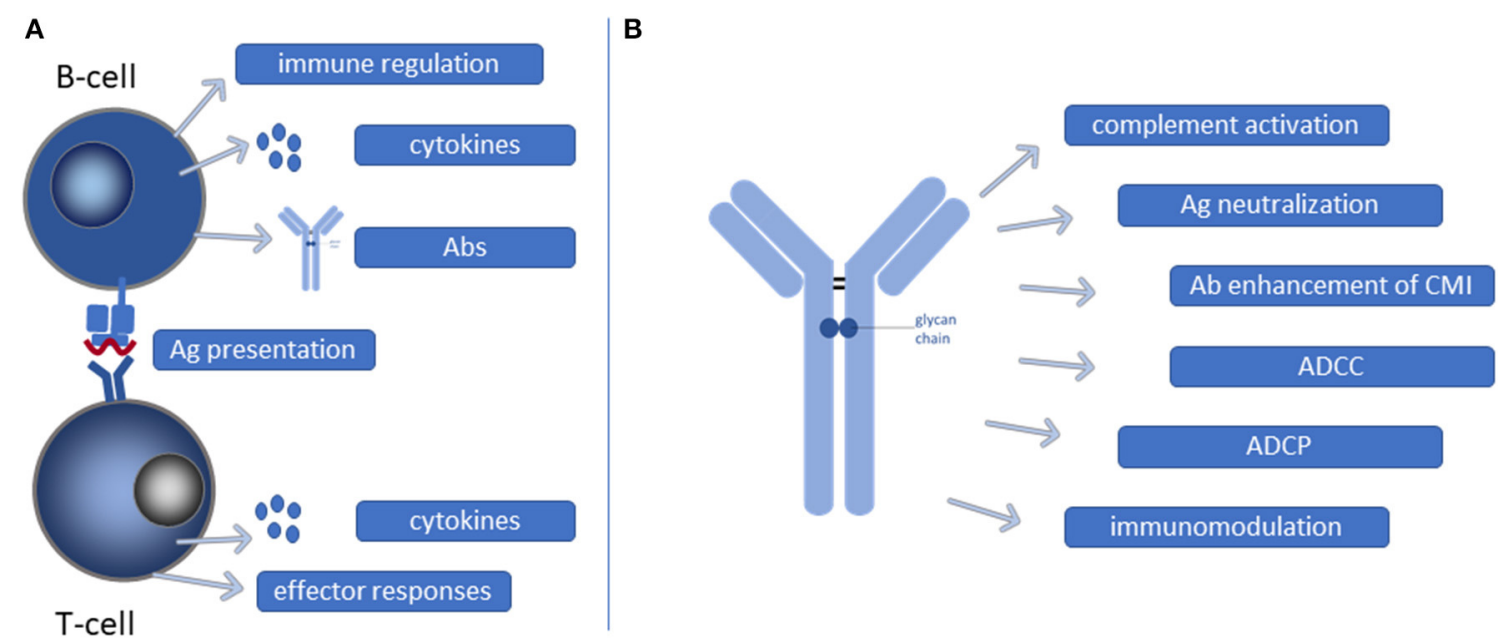

FIGURE 2 | Functional contribution of B-cells and Abs during Mtb infection. (A) B-cells may present mycobacterial antigens (Ags) as professional antigen presenting cells to T-cells resulting in T-cell activation and CMI. Moreover, B-cells, as well as activated T-cells, secrete cytokines that contribute to shaping of effector responses. Furthermore, B-cells can also have direct immunoregulatory functions and secrete Abs. (B) Ab binding to Mtb can initiate a multitude of different processes, each contributing in their own way to reduction of the mycobacterial burden. CMI, cell mediated immunity; ADCC, antibody dependent cellular cytotoxicity; ADCP, antibody dependent cellular phagocytosis.

increased frequencies of marginal zone $\left(\mathrm{CD} 19^{+} \mathrm{CD} 21^{+} \mathrm{CD} 23^{-}\right)$ B-cells in QuantiFERON-TB Gold In-Tube test (QFN) positive compared to QFN-negative individuals (136).

Studies characterizing and enumerating B-cell phenotypes during TB not only analyzed the presence of various B-cell subpopulations in peripheral blood, but also in the lungs and pleural cavity. Approximately $85 \%$ of B-cells present in both unaffected and Mtb-infected mouse lungs expressed surface markers typical of follicular B-cells or B2-cells (e.g. $\mathrm{CD}_{1} 9^{+} \mathrm{B} 220^{\text {high(hi) }} \operatorname{IgM}^{\text {low(lo) }} \operatorname{IgD}^{\text {hi }}$ with the phenotype $\mathrm{CD} 21 / 35^{+} \mathrm{CD} 1 \mathrm{~b}^{-} \mathrm{CD} \mathrm{d}^{-} \mathrm{CD} 5^{-} \mathrm{CD}^{-} 3^{-}$), whilst $15 \%$ exhibited a surface expression that is characteristic of antibody producing B1-cells (e.g. $\mathrm{CD}_{19}{ }^{+} \mathrm{B} 220^{\mathrm{lo}} \mathrm{IgM}^{\mathrm{hi}} \mathrm{IgD}^{\mathrm{lo}} \mathrm{CD} 23^{-} \mathrm{CD}^{-} / \mathrm{CD}^{-}$) (128). In the lungs, the $\mathrm{B} 1 / \mathrm{B} 2$ ratio was comparable between infected and uninfected mice. In the pleural cavity, however, progression of TB was associated with an elevated proportion of the B2-population (from 25 to 60\%) (128).

Another important B-cell subset are regulatory Bcells (Bregs), which balance immune activation following inflammatory responses during infection. An increased frequency of $\mathrm{CD} 19^{+} \mathrm{CD} 1 \mathrm{~d}^{+} \mathrm{CD} 5^{+}$Bregs in the circulation of ATB-patients coincided with increased inhibition of T-helper (Th) 17 responses and interleukin-22 (IL-22) generation, while Th1 responses remained unchanged (132, 137). The fact that this Breg-subpopulation was also present in healthy donors, but with decreased suppressive activity, suggests that $\mathrm{CD} 19^{+} \mathrm{CD} 1 \mathrm{~d}^{+} \mathrm{CD} 5{ }^{+}$Bregs have activity regulated in response to infection (137). Furthermore, patients with cavitary TB, a severe clinical manifestation of ATB, had increased numbers of $\mathrm{CD}_{1}{ }^{+} \mathrm{CD} 1 \mathrm{~d}^{+} \mathrm{CD} 5{ }^{+}$Bregs in the peripheral blood in comparison to ATB-patients without cavitation (132). Thus, $\mathrm{CD} 19^{+} \mathrm{CD} 1 \mathrm{~d}^{+} \mathrm{CD}^{+}$Bregs might dampen protective antiMtb effector responses, and indeed Mtb Ag-specific IL-22 responses during ATB-treatment were related to reduced $\mathrm{CD} 19^{+} \mathrm{CD} 1 \mathrm{~d}^{+} \mathrm{CD} 5{ }^{+}$Breg numbers (132).

Another type of Bregs includes a rare subset, called killer B-cells $\left(\mathrm{CD} 19^{+} \mathrm{CD}^{+} \mathrm{IgM}^{+}\right)$, which are characterized by Fasligand (FASL, CD178) expression (138). Reduced levels of FASL transcript, a diminished incidence of FASL expressing Bcells and a lower level of soluble FASL were detected in the bronchoalveolar lavage (BAL) fluid of ATB-patients at diagnosis compared to the end of successful anti-TB treatment (139). The expression of FASLG and IL5RA was lower in ATB-patients compared to healthy controls, but upon anti-TB treatment, levels were completely restored (140). The frequency of FASL expressing B-cells was lower in whole blood from ATB-patients compared to healthy controls (138). FASL expressing B-cells were present during both ATB and LTBI, but the frequency of this Breg-subset was higher in LTBI and was even further elevated after B-cell re-stimulation with BCG (138). Thus, killer B-cells may contribute to protective immunity during Mtb-infection. Further work is required to decipher the exact role of killer B-cells during Mtb-infection.

Overall, these data implicate that the relative frequencies and function of B-cell subsets are affected during Mtb-infection, "protective" B-cell subsets are decreased in numbers, whilst potentially pathological B-cell subpopulations are increased during ATB-disease. Importantly, patients cured from ATBdisease have normalized B-cell numbers, with normal phenotype distributions and functional properties, indicating restoration of the responses.

\section{B-Cell Modulation of Effector Cells During Mtb-Infection}

$\mathrm{B}$-cells are players in the formation of effective immune responses since B-cells are not only potent APCs, but also represent 
powerful producers of a wide range of cytokines and Abs $(7,37)$. All of these B-cell features can influence the function of a broad range of immune cells, such as T-cells, macrophages, neutrophils and dendritic cells.

\section{B-Cells Guiding T-Cell Responses B-Cell Antigen-Presenting Capacity as Modulator of T-Cell Immunity}

The ability of B-cells to function as APCs may contribute to the orchestration of Mtb specific CD4 ${ }^{+}$T-cell immunity (60). Surprisingly, Ag presentation by B-cells during Mtb-infection has hardly been assessed $(128,141)$. In B-cell deficient mice, it was demonstrated that correct programming and induction of effector cells specific for Mtb Ags necessitated presentation of these particular Ags to $\mathrm{CD}^{+}{ }^{-}$T-cells by B-cells (141). Moreover, aerosol challenge of genetically Mtb-susceptible I/St mice slightly increased the level of major histocompatibility complex-class II molecules on the surface of lung B-cells during Mtb-infection, and their efficacy to present Mtb Ags to CD4 ${ }^{+} \mathrm{T}$ cells was comparable to that of their splenic counterparts (128). Importantly, the APC-function of B-cells during Mtb-infection appears to become progressively more relevant at lower Ag load, but likely superfluous at higher Ag loads (142, 143). The Ag-presenting potential of B-cells was also shown to increase vaccine-effectiveness (including TB-vaccines), and to strongly boost BCG primed immunity (144-146).

\section{B-Cells and Their Cytokines as Powerful T-Cell Rheostats}

B-cells isolated from lungs of Mtb-infected mice produced and released a wide range of cytokines $(7,37)$. In a cynomolgus macaque (Macaca fascicularis) model a role for granulomatous Bcells in producing IL- 6 and IL-17 was discovered, and to a lower degree IL-10 and IFN- $\gamma$, during the acute phase of Mtb-infection (74). B-cell depletion, however, only resulted in diminished secretion of IL-6, but not IL-17 (74), suggesting functional cellular interactions for B-cells in lesions. In agreement with the ability of B-cells to produce IL-6, Linge et al. demonstrated that lung B-cells in I/St mice can secrete high to moderate levels of proinflammatory IL- 6 and IL-11 when challenged with Mtbstrain $\mathrm{H} 37 \mathrm{Rv}$ (128). Atypical B-cells with reduced production of intracellular IL- 6 were isolated from the blood of both ATB and LTBI patients (116). Taken the diverse stages of TB disease into consideration, du Plessis et al. attempted to map the B-cell derived cytokine profile during LTBI (147). B-cells could produce both pro- and anti-inflammatory cytokines when stimulated with Mtb (or TLR agonists), including IL-1 $\beta$, IL-10, IL-17, IL-21 and tumor necrosis factor-alpha (TNF- $\alpha$ ) (147).

$\mathrm{B}$-cells produce and release specific cytokines upon activation, and thereby a.o. shape (T-cell) immune responses against Mtb. Specifically, IL- $1 \beta$ and IL- 6 have been reported to play a critical role in establishing and sustaining Th17-responses to Mtb (148-150). In addition, IL-6 directs differentiation of Th1-cells from naïve T-cells (151). Although the function of IL-11 in anti-Mtb immunity remains to be elucidated, in multiple sclerosis this cytokine is a potent stimulator of Th17 responses $(152,153)$. Moreover, IL-21 has been shown to play a critical role in $\mathrm{T}$-cell immune responses against
Mtb by enhancing $\mathrm{CD}^{+}{ }^{+} \mathrm{T}$-cell priming, increasing $\mathrm{T}$-cell accumulation in the lungs and potentially by inhibiting T-cell exhaustion (148). Similarly, TNF- $\alpha$ has been shown to enhance T-cell responses through augmenting Ag-presentation and crosspriming (154). Furthermore, both TNF- $\alpha$ and IL-17 can regulate chemokine-expression and thereby modulate the recruitment and maintenance of immune cells, including T-cells, at the site of infection (155-157). In contrast, IL-10 can dampen Mtbspecific Th1 responses through inhibition of TNF- $\alpha$ and the Th1polarizing cytokine IL-12 and human leukocyte antigen-class II expression, thereby limiting Ag-presentation, cross-priming and migration of Th1-cells toward the lungs (158-161). Collectively, these data point to an important role for B-cell produced cytokines in the generation and regulation of CMI to TB.

\section{THE MECHANISTIC ROLE OF Abs IN TB}

Besides their antigen presentation capacity and their ability to skew T-cell responses through cytokine secretion, B-cells are best known for their capacity to secrete Abs. Like B-cells, Abs exist in multiple isotypes and subclasses, each with distinctive functional properties, which are further diversified by post-translational modifications, representing an enormous functional potential for Abs in effector immunity toward Mtb (Figure 2B). TB disease, but not Mtb infection itself, may significantly alter the functional properties, including the avidity, of Abs against heterologous (162), reflecting modification of humoral responses by Mtb likely by altering B-cell function. In this chapter, we will focus on the Mtb specific responses.

\section{Abs as Potential Biomarkers for Protective Immunity Against Mtb}

"Natural immunity" against Mtb has recently been studied in various human "resistor" or "early clearers" cohorts, amongst which were health care workers (76), household TB contacts (163-165) and gold miners (166). These studies consistently identified that $\sim 5-15 \%$ of the tested individuals in a TBendemic region are resistant to acquire latent $\mathrm{Mtb}$-infection as determined by tuberculin skin test (TST) or QuantiferonTB Gold (QFT) conversion (167). Genome-wide linkage analysis in a panel of South African families living in a hyperendemic area demonstrated that the locus called TST1 was associated with TST reactivity (168). A deep sequencing study showed preferential rearrangement of $\mathrm{V}_{\mathrm{H}} 3-23-\mathrm{D} 3-3-\mathrm{J}_{\mathrm{H}} 4$ fragments in IgA molecules in TST-negative nurses with long-term exposure to Mtb compared to their TST-positive colleagues (169). Moreover, healthy nurses in a TB ward had a strong Ab-response specific toward the TB69 epitope of the $14-\mathrm{kDa} \mathrm{Ag}$, possibly linked to resistance to acquiring Mtb-infection (170). Individuals with persistent negative TSTs, despite years of exposure to ATB patients, had elevated anti-Mtb IgG levels, and their serum was able to block proliferation of peripheral blood mononuclear cells in response to protein purified derivative (PPD) (171). In concordance, highly exposed, but TST-negative, Colombian individuals displayed high anti-PPD Abs titers, which inhibited autologous T-cell proliferation after PPD stimulation (172). 
Abs specific for CFP-10 and ESAT-6 in QFT supernatants independently separated LTBI from ATB (173). More recently, $\mathrm{Lu}$ et al. reported that highly exposed, but TST- and IFN- $\gamma$ release assay (IGRA)-negative, Ugandan individuals harbored Mtb-specific IgM and IgG, while diminished CD4-mediated IFN- $\gamma$ responses directed toward Mtb early secreted Ag of 6 $\mathrm{kDa}$ (ESAT-6), $10 \mathrm{kDa}$ culture filtrate protein (CFP-10), Ag85A and Ag85B were found (163). Taken together, these studies implicate that humoral immunity is detectable in frequently exposed individuals with persistently negative skin testing or QFN evaluation, which represent read-outs of effector T-cell responses. In such settings, Abs may be considered biomarkers of protective immunity.

\section{Ab Effector Functions Against Mtb}

Although Abs may be interesting biomarkers of Mtb-infection or resistance to disease progression, they may also contribute functionally to reduce bacterial loads. However, when considering a role in prevention of infection Abs need to localize to sites where the pathogen enters the host to inhibit, or contribute to early clearance of, infection. In addition, Abs need to trigger the right effector responses, therefore functional assessment rather than mere quantification is critical to evaluate the contribution of Abs to the immune response. Typically, Abs are located in both the upper and lower respiratory tract, where $\operatorname{IgA}$ dominates in the upper airways and $\operatorname{IgG}$ in the lower airways. It has been shown that human infection with Mtb resulted in mycobacterial specific IgA and IgG in BAL fluid $(174,175)$. Abs can bind Mtb-specific Ags at the site of disease $(30,60)$, such as the tuberculous granuloma where plasma cells have been demonstrated to secrete Abs (112), which could potentially interact with extracellular Mtb and/or free Mtb Ags present in the granuloma itself, or in the pleural fluid $(112,176,177)$. In addition, Mtb is extracellular during its reinfection phase and during expectoration. Thus, in spite of being a facultative intracellular pathogen, $\mathrm{Mtb}$ is possibly susceptible to numerous mechanisms of $\operatorname{AMI}(6,178)$. These comprise, but are not limited to, mycobacterial neutralization $(82,91,179)$, antibody-dependent cellular phagocytosis (ADCP) (180, 181), complement activation (182-184), antibodydependent cell-mediated cytotoxicity (ADCC) (185), Mtb-Ab immune complex sensing by intracellular FcR tripartite motifcontaining protein 21 (TRIM21) (186, 187), stimulation of CMI (43, 188, 189) and modulation of the strength and nature of the inflammatory response during Mtb-infection $(6,31,36,69,185,190-193)$.

\section{Ab-Dependent Opsono-Phagocytosis of Mtb}

One of the most important $\mathrm{Ab}$ effector functions against $\mathrm{Mtb}$ is opsono-phagocytosis, also called ADCP (63). ADCP is mediated by mononuclear phagocytes and granulocytes upon engaging FcRs or, following complement opsonization, complement receptors (42). Mtb inhibits phagosome-lysosome fusion to evade exposure to the antimicrobial lysosomal content (194-197). However, Ab-mediated phagocytosis of opsonized mycobacteria can overcome this inhibition by triggering phagolysosomal fusion (197). Similarly, more recent studies have found increased phagosome maturation in the presence of opsonizing
Abs and showed decreased mycobacterial viability upon phagolysosomal fusion $(180,181,189,198)$. Opsonizing Abs restricted Mtb growth in macrophages by significantly increasing the microbicidal potency through increased lysosomal-associated membrane protein 1 (LAMP-1; a phagosome maturation marker) and inducible nitric oxide synthase (iNOS) phagosomal localization and enhanced phagosome acidification, as well as by increased levels of the proinflammatory cytokines IFN- $\gamma$ and IL-6 (194). Another study described that IgGcoated BCG induced increased microbicidal activity by alveolar macrophages associated with an elevated oxidative burst in phagosomes (199). Mtb opsonized with LAM-specific Abs bound Fc $\gamma$ Rs on macrophages and stimulated mycobacterial killing, which was associated with increased calcium $\left(\mathrm{Ca}^{2+}\right)$ concentrations that promoted phagosome maturation (196). Uptake of Mtb mannose-capped LAM (ManLAM) beads into human alveolar macrophages via mannose receptors initiated a specific phagocytic pathway that limited phagosomal fusion, whereas phagocytosis of anti-LAM mAb coated beads through Fc $\gamma$ Rs did not inhibit the fusogenic property of phagosomes (200). In agreement with these results, uptake of phosphatidylmyo-inositol mannoside (PIMs)-coated beads into macrophages via engagement of mannose receptors resulted in restricted phagolysosomal fusion (201). Thus, Mtb cell entry via mannose, complement- and probably other phagocytic receptors allows intracellular survival and replication of bacilli by limiting phagosome maturation while on the other hand, increased phagolysosomal fusion is observed after phagocytosis of Abopsonized mycobacteria via FcR signaling (198). Indeed, Chen et al. have demonstrated that increased Mtb phagocytosis and the subsequent increased phagolysosomal fusion observed in THP-1 cells infected with Mtb opsonized with sera containing high anti-AM IgG titers derived from asymptomatic volunteers, was Fc $\gamma \mathrm{R}$ mediated (180). Furthermore, a significant decline in Mtb phagocytosis by human anti-Mtb Abs was observed when blocking Fc $\gamma$ RI (CD64), which was even more prominent when Fc $\gamma$ RI (CD32) was blocked. In contrast to (180), $\mathrm{Lu}$ et al. found that enhanced functionality of polyclonal LTBI IgG was correlated with selective Fc $\gamma$ RIII (CD16) binding, which was associated with increased phagosome maturation and elevated macrophage killing of intracellular tubercle bacilli (185). Intriguingly, CD16 positive, non-classical monocytes were strongly associated with reduced mycobacterial outgrowth upon recent Mtb exposure (202). The discrepancies between studies can likely be attributed to differences in Abs related to the stage of TB disease, and differences in assays and phagocytosing cells $(203,204)$, as THP-1 cells do not express Fc $\gamma$ RIII (CD16), whilst monocyte-derived macrophages do $(205,206)$. In summary, $\mathrm{Ab}$ opsonization of $\mathrm{Mtb}$ and subsequent $\mathrm{FcR}$ signaling can target Mtb to the degradative lysosomal pathway, which is directly antimicrobial even though it may not be capable to induce complete elimination (194).

\section{Ab-Mediated Classical Complement Activation in TB Disease}

An additional mechanism by which AMI could influence the host response against $\mathrm{Mtb}$ is through Ab-mediated complement engagement and deposition (182-184). As discussed 
previously, transcripts of different complement genes were strongly increased during active TB-disease, which were considered important biomarker candidates (18, 20, 23-26). In addition, increased concentrations of circulating immune complexes were detected in serum of patients with subclinical and clinical ATB (24), however, the antigen in these complexes remains unknown. In Indian TB patients anti-LAM IgG2, but not IgM, was associated with classical pathway complement activation (184). Likewise, human IgG, and to a lesser degree IgM, was shown to increase complement deposition on BCG via classical pathway activation (183). Moreover, human anti-Mtb IgG augmented complement activation resulting in enhanced phagocytosis of Mtb by macrophages (182). Thus, complement activation by anti-Mtb Abs seems possible, but has been investigated to a very limited extent, nonetheless, it may significantly contribute to Mtb phagocytosis.

\section{Ab-Mediated Cellular Cytotoxicity in TB Disease}

ADCC might represent another classical mechanism that could possibly help controlling Mtb. IgG-mediated ADCC might stimulate killing of $\mathrm{Mtb}$ and could play a vital role in the early containment of Mtb upon their re-entry into the extracellular space. Indeed, PPD specific IgG from both LTBI and ATBpatients increased natural killer (NK) cell-mediated ADCC (185). IgG derived from LTBI patients revealed a preferential interaction with the activating Fc $\gamma$ RIIIa (CD16a) associated with an increased on-rate in comparison to IgG isolated from ATB patients (185). This enhanced Fc $\gamma$ RIIIa (CD16a) binding profile correlated with increased NK cell activation, elevated ADCC and enhanced Mtb control. These findings suggest a protective role for ADCC in host defense against Mtb.

\section{Intracellular Sensing of Mtb-Ab Immune Complexes by TRIM21}

Going beyond Ag-Ab immune complex recognition by classical FcRs, Ab binding to Mtb might also be detected intracellularly via the ubiquitously expressed cytosolic Ab FcR called TRIM21. Interestingly, the TRIM21 pathway was identified as important pathway in $\mathrm{TB}$ when interconnectivity of multiple biomarkers was analyzed in unbiased transcriptomic studies, suggesting TRIM21 may not only be a biomarker of TB-disease, but also functionally involved in reducing the bacterial load (8). Abcoated pathogen binding to TRIM21 has been demonstrated to result in the activation of signaling pathways, including nuclear factor kappa-light-chain-enhancer of activated B-cells $(\mathrm{NF}-\kappa \mathrm{B})$, activator protein (AP)-1 and the IFN-regulatory factor (IRF) family, and stimulate the production of proinflammatory cytokines via K63-linked ubiquitination (186, 187). Hence, TRIM21 triggering elicits an anti-pathogenic state and can provide protective immunity against non-enveloped viruses and intracellular bacteria, such as adenoviruses, Salmonella enterica and Toxoplasma gondii (186, 187, 207, 208). Importantly, a requirement for TRIM21-mediated signaling and neutralization includes relocation of Abs from the extracellular space toward the cytosol, where Abs are normally not found $(186,187)$. In the case of $\mathrm{Mtb}$, the bacillus is able to disrupt the phagosomal membrane, which allows Mtb together with bound Abs to enter the cytosol
(209). Thus, the cytosolic localization of both Mtb specific Abs and TRIM21 in combination with the circumstantial evidence described above might open up attractive new roles for Abs in the battle against Mtb.

\section{The Role of Abs in Mucosal Immunity Against TB}

The cumulative work presented above clearly indicates the pleiotropic effect of $\mathrm{Abs}$ in the immune response to $\mathrm{Mtb}$, in which the particular $\mathrm{Ab}$ effector function utilized is dependent on Ag specificity, Ab isotype and subclass (28, 42, 59, 210). The pulmonary compartment represents the predominant route of Mtb-infection, and the distribution of Ig isotypes in the mucosal lining includes predominantly secretory $\operatorname{IgA}$ (sIgA), lower amounts of soluble IgM, and even lower soluble IgG. Belay et al. have demonstrated that exposed healthy controls have a significantly increased anti-HBHA IgA titer in comparison to untreated TB-patients and their QFN-negative household contacts at baseline, suggesting that anti-HBHA IgA could function as a biomarker for immune control of Mtb (211). Mucosal BCG-vaccination by bronchial instillation in rhesus macaques induced pulmonary $\operatorname{IgA}$ (measured in BAL fluid), which correlated with protection against low-dose TB-challenge (212). Interestingly, another strongly protective regimen, intravenous BCG-vaccination, also induced increased levels of pulmonary IgA in NHPs (213). Thus, local IgA may represent a correlate of protection, and may functionally contribute to control of mycobacteria.

For functional assessment, polyclonal human sIgA purified from colostrum from healthy volunteers was found to be reactive to both BCG and Mtb Ags (214). Prophylactic intratracheal incubation or pre-incubation of tubercle bacilli with human sIgA resulted in reduced $\mathrm{Mtb}$ viability, which was associated with reduced lung tissue damage, as indicated by better granuloma organization and smaller pneumonic areas in the lungs of Mtb-infected mice. Likewise, when $\operatorname{IgA}$ deficient $\left(\operatorname{Ig} \mathrm{A}^{-/-}\right)$ and WT littermate mice were intranasally inoculated with the mycobacterium surface phosphate-binding protein PstS-1 (215), $\mathrm{IgA}^{-/-}$mice were still capable of generating PstS-1 specific IgM and IgG, but revealed an increased susceptibility to BCG infection in comparison to WT mice: this was indicated by elevated mycobacterial loads in the lungs at 4 weeks postinfection, and decreased production of IFN- $\gamma$ and TNF- $\alpha$. Similarly, mice lacking the polymeric immunoglobulin receptor (pIgR) that enables IgA transcytosis, inoculated with PstS-1 Ags, developed decreased PstS-1 specific IgA titers in their saliva (216). These mice additionally showed increased susceptibility to intranasal BCG, which again correlated with an impaired Th1-response, as manifested by diminished IFN- $\gamma$ and TNF- $\alpha$ levels in the lungs, and with delayed and reduced mycobacterialinduced immune responses during early infection. These studies collectively indicate that sIgA participates in protection against Mtb-infection and this effect is mediated via modulation of the inflammatory response at the mucosal level and/or by immune exclusion, a process that refers to the capability of sIgA to prevent 
pathogens and Ags from acquiring entry to the epithelium (217, 218).

Given the importance of mucosal IgA in host defense against Mtb (219), significant prophylactic and therapeutic improvement could be achieved when eliciting a mucosal immune response at the port of Mtb entry in addition to a systematic immune response. Passive immunization with $\mathrm{mAbs}$ has opened avenues for potential protective roles of mucosal IgA and the ability to explore different routes of delivery and their subsequent effects. In fact, in a mouse model of mycobacterial lung infection, intranasal immunization of mice with an IgA $\mathrm{mAb}$ (TBA61) directed against Mtb Acr1, induced a transient reduction in bacterial counts in the lungs following aerosol or intranasal challenge (88). This protective effect was improved and prolonged (3-4 weeks) when the $\mathrm{Ab}$ was co-administered with mouse recombinant IFN- $\gamma$ alone (87) or in combination with IL4 neutralization (86) and was demonstrated to be both isotype and epitope specific (88). This finding is in agreement with the observation that intratracheal mAb TBA61 pre-treatment resulted in decreased mycobacterial loads in mouse lungs, which was correlated with milder histopathology following Mtbchallenge (85). More recently, it has been shown that in human Fc $\alpha$ R (CD89) transgenic mice, intranasal administration of a human IgA1 mAb specific for Acr1 combined with recombinant mouse IFN- $\gamma$ significantly reduced bacterial load after intranasal Mtb-infection. Thus, the observed protective effect of IgA in this setting was FcaR (CD89) dependent $(81,83)$. Collectively, IgA $\mathrm{mAb}$ can influence the intracellular fate of Mtb via potentiation of mycobactericidal functions of infected macrophages and by modulation of the inflammatory response $(87,219-221)$.

Together, the work described above highlights the importance of mucosal immunity in host defense against Mtb. Although local IgA production correlated with protection induced by intravenous or mucosal BCG vaccination, its functional capacity to control mycobacteria remains to be demonstrated.

\section{Glycosylation Patterns as Modulators of Ab Functionality in TB}

Modification of Abs, like glycosylation, influences the function of Abs (222). These glycans modify the Ab Fc region structure, and addition or removal of glycan-molecules modifies $\mathrm{Ab} F \mathrm{FR}$ engagement and $\mathrm{Ab}$ functionality $(222,223)$. Specifically, recent new data obtained from several viral and bacterial diseases implicate that infection, and the associated inflammatory state of the individual, alters $\mathrm{Ab}$ glycosylation and hence functionality $(224,225)$.

Given the dynamic nature of glycan alterations that is impacted by the inflammatory milieu (226), Ab glycosylation changes could also occur during the course of TB disease. Using systems serology, Lu et al. showed that the LTBI Ab glycome of total and PPD-specific IgG had accumulated digalactosylated (G2) glycans with an increased level of sialylation, but less core fucosylation in comparison to ATB IgG (185). This finding resonates with the observation that individuals with ATB displayed a marked elevation of agalactosylated (G0) and asialylated IgG glycans (227-229). Although the absence of galactose is considered to be correlated with increased inflammatory activity in general $(223,226)$, agalactosylated (G0) IgG could trigger the lectin complement pathway (230). The presence of sialic acid has been correlated with an antiinflammatory state in rheumatoid arthritis patients (231), and this could reflect diminished inflammation in LTBI compared to ATB patients. Increased Fc $\gamma$ RIIIa (CD16a) engagement by polyclonal IgG from LTBI individuals led to increased Mtbspecific ADCC and killing of tubercle bacilli in infected primary human monocyte-derived macrophages in comparison to purified IgG derived from ATB-patients (185). Interestingly, NK-cell frequencies and CD16 function were associated with LTBI (124). Together, these data highlight that the discrete Ab glycosylation patterns observed in LTBI persons might correlate with increased Mtb control.

Removal of polysaccharides from purified IgG decreased the level of ADCP, showing that Ab glycosylation is essential for anti-Mtb activity (185). Glycosylation profiles differed for divergent $\mathrm{Mtb}$ reactive $\mathrm{Ab}$ populations (e.g., recognizing PPD and Ag85A), suggesting possible differential modulation of glycosylation across IgGs against different Mtb-specific Ags (232). Furthermore, parallel profiling of whole IgG and Agbinding fragment (Fab) and Fc region-specific IgG glycosylation, showed that the main alterations in Ab glycan moieties across divergent TB-disease states (185) were located in the Fcregion. Stringent multivariate analysis further demonstrated that Fc-region glycosylation can distinguish between LTBI and ATB disease states (232). Digalactosylated (G2) glycan structures and the discrete structure G1S1F (characterized by one galactose, one sialic acid, and one fucose) located on the IgG-Fc region discriminated LTBI from ATB individuals, and likewise distinguished successfully treated ATB individuals from ATB patients (Grace et al., under review). In addition, Mtb-specific IgG4 titers were identified as a novel biomarker for TB disease, in which IgG4 levels were increased during ATB compared to LTBI and individuals that had successfully completed TB-treatment. IgG4-depletion increased Ab effector function, suggesting regulation of the overall humoral response. In addition, LTBI individuals could be distinguished from successfully treated ATB patients by lower Mtb-specific IgM and IgG1 levels and decreased opsono-phagocytic function (Grace et al., under review). Mtb resisters (characterized as highly Mtb exposed individuals that persistently tested negative in both TST and IGRA), similar to health care worker cohorts described above, revealed distinct PPD-specific IgG Fc-glycosylation patterns compared to individuals with LTBI, in which their IgG showed accumulated monogalactosylated (G1) glycans with an increased level of fucosylation and bisecting GlcNAc, but less core sialyation (163). These selectively enriched glycan structures were associated with increased NK cell IFN- $\gamma$ release facilitated by augmented Fc $\gamma$ RIIIa (CD16a) engagement leading to better in vitro Mtb control $(124,185)$. Collectively, Mtb-specific Fcglycosylation may serve as biomarker to differentiate between ATB and LTBI.

Based on the wide variety of $\mathrm{Ab}$ effector functions available, AMI can significantly contribute to protection against $\mathrm{Mtb}$ at different stages of infection. Moreover, B-cells and Abs, 
specifically mucosal IgA, might also be useful biomarkers for vaccine induced protective immunity against Mtb. However, the majority of studies only include quantification of Ab levels, while not taking into account functional assessment of Mtb-specific Abs. Hence, more functional read-outs are needed for B-cells and Abs to evaluate them as correlates of protection and to gain a deeper understanding of the quality of humoral immunity during different stages of Mtb-infection (Figures 1, 2).

\section{B-CELLS AND Abs AS TARGETS FOR VACCINATION}

The majority of designed novel TB-vaccines has concentrated on the induction of CMI $(64,233)$. Some vaccines, including BCG, induce memory as reflected by the detection of PPD specific memory B-cells (234). However, several recent vaccine studies in mice, NHPs and humans have shown significant induction of Abs against Mtb as well, which might contribute to the vaccine efficacy observed.

Prados-Rosales et al. (235-240) conducted a study with a TBvaccine that selectively elicits AMI against the tubercle bacillus (241). More specifically, two polysaccharide (PS)-conjugate vaccines were created, by linking the capsular PS AM to either Ag85b or to Bacillus anthracis protective Ag. Both PSconjugate vaccines substantially diminished lung inflammation and mycobacterial dissemination to the spleen in mice challenged with virulent $\mathrm{Mtb}$. More importantly, passive transfer of immune serum derived from AM-immunized mice offered protection, as assessed by decreased mycobacterial loads in both the lungs and spleen when delivered before aerosol Mtb-infection of naïve mice (241). Corroborating these data, mice immunized with a PS-conjugate vaccine of Ag85b and AM generated high AMspecific IgG levels and showed protection against Mtb, reflected by both prolonged survival and diminished lung pathology (239). More recently, booster vaccination with a whole cell inactivated vaccine (heat-killed MTBVAC) increased protection against Mtb after intranasal vaccination of BCG-primed mice in comparison to subcutaneous BCG only (235). This improved protection correlated with induction of PPD-specific Abs in the BAL fluid that opsonized Mtb. These data were supported by similar data obtained in NHPs (235).

In other NHP studies, vaccine-induced local $\mathrm{Ab}$ responses correlated with protection against $\mathrm{Mtb}$-infection and disease (212). BCG vaccination was delivered to rhesus macaques either via the standard intradermal route or via endobronchial instillation, a mucosal route of immunization, which resulted in strong protection against subsequent repeated low-dose infection with $\mathrm{Mtb}$, as measured by reduced lung bacillary loads and diminished histopathology. Interestingly, mucosally vaccinated rhesus macaques had high levels of Ag-specific IgA locally in the BAL fluid. Similarly, intravenous administration of BCG in rhesus macaques induced protection against $\mathrm{TB}$ and superior Mtb-specific IgG, IgA and IgM responses in BAL fluid and plasma in comparison to intradermal BCG vaccination (213). Together, these studies describe an association between (local) humoral immune responses and protection against Mtb after
BCG immunization, putting humoral immunity forward as a potential correlate of protection.

In humans, several TB-vaccine trials showed correlations between specific Abs and vaccine efficacy against Mtb-infection and/or disease. In a large-scale phase $2 b$ efficacy trial in BCG vaccinated South African infants, utilizing the recombinant vaccinia Ankara virus modified to express Ag85A (MVA85A) (242), the presence of Ag-specific IgG titers correlated with a reduced risk of developing TB disease (101). Furthermore, protection was achieved using a subunit vaccine in the M72/ASO1E vaccine trial (243). This clinical phase $2 \mathrm{~b}$ trial demonstrated that the incidence of ATB disease was significantly reduced in Mtb-infected adults vaccinated with $\mathrm{M} 72 / \mathrm{ASO} 1_{\mathrm{E}}$ relative to placebo. Besides robust activation of $\mathrm{T}$-cells, the vaccine also elicited a strong Ag-specific IgG response that persisted up to at least 36 months post immunization $(244,245)$. Thus, collectively, the data obtained from mouse, NHP and human vaccination studies support the possibility that AMI might contribute to the protective effects of certain TB-vaccines.

\section{Preventive and Therapeutic TB-Vaccine Design}

An ideal anti-TB-vaccine would protect against both Mtbinfection in exposed individuals and the establishment of disease in already Mtb-infected persons. There is a desperate need for the development of more effective TB-vaccines for children, adolescents and adults. To that end, the emerging appreciation of the role of B-cells and Abs in combatting Mtb $(6,7,30$, $31,37)$ in combination with the existence of naturally arising human Abs that are probably functionally protective against Mtbinfection (76), points toward an exciting and promising new path to explore.

BCG as neonatal vaccination against $\mathrm{TB}$ has not only reduced the incidence of severe forms of $\mathrm{TB}$ in children, but has also reduced all-cause childhood mortality as a result of heterologous protection against non-related pathogens (246249). BCG vaccinated children had increased levels of Abs in their serum indicating enhanced activation of cell-mediated responses, in particular of humoral immune components (246249). Although most studies focused on heterologous protection in young children, more recently, it was suggested that also vulnerable elderly could benefit from BCG vaccination to protect against unrelated pathogens $(250,251)$. BCG did not only enhance responses against natural infections, but also increased the magnitude of humoral responses induced by vaccines against non-related pathogens (246). The mechanism behind these heterologous protective effects is called trained innate immunity and reflects an increased state of responsiveness of mostly innate immune cells due to epigenetic alterations and metabolic rewiring independent of $\mathrm{Ag}$ (252). However, it is unknown if similar processes may also alter the response-readiness state of Ag specific adaptive immune players, in particular because the reprogramming occurs in the hematopoietic stem and progenitor compartment (253). Nevertheless, training of innate players by live vaccines, most prominently BCG, will have significant effects on the magnitude of both innate and adaptive responses, 
including humoral immunity, which will significantly contribute to vaccine induced protection. Novel live vaccines may have a similar training capacity, in particular BCG variants or live attenuated Mtb strains, and thereby might enhance humoral responses, however for other vaccine formulations this remains to be investigated. Prime-boost regimens, including those with a BCG prime, may be superior in activating B-cells partly by enhanced, trained status of key players. A more detailed analysis of these effects for each of the novel vaccine candidates is strongly encouraged.

For the development of a TB-vaccine that elicits not only cellular, but also functional humoral responses, it is of importance to take the route of delivery into consideration (254). Pre-exposure vaccines that aim at preventing infection with $\mathrm{Mtb}$ may need to induce IgA production locally in the lungs (255), whereas post-exposure vaccines that aim to either modify or prevent clinical disease in already Mtb-infected individuals most likely will need to trigger a systemic response including $\operatorname{IgG}(180)$.

\section{DISCUSSION}

Mycobacterial tuberculosis remains a challenging and threatening pathogen, affecting many people globally. Ample epidemiological studies indicate that progression of disease is strongly associated with the immunological competency of the host, and therefore, a more in-depth understanding of the effector anti-TB immune responses is pivotal for the design of next-generation preventive and therapeutic approaches in the fight against this pathogen. The complementary effect of immune components other than classical Th1/Th17 cellular responses, such as Abs, should be considered. Abs and B-cells on their own may not be sufficient to combat Mtb, however there is accumulating evidence that they can complement and enhance CMI. Clinical vaccine evaluation studies should incorporate not only the quantitative assessment of these responses, but also their functional capacity to reduce $\mathrm{Mtb}$ burden to assess their future value as correlates of protection and as mediators of protection (Figure 1).

The majority of $\mathrm{Ab}$ studies largely concentrated on their utility as diagnostic tools, with little to no attention for dissection of Abs at the isotype and subclass level in relation to TB pathogenesis and resolution (256). However, both $\mathrm{Ab}$ isotype, subclass and post-translation modifications might alter functional properties toward Mtb (180). Such differences are most likely a result of structural, antigenic and functional divergences in the Fab and $\mathrm{Fc}$ region of $\mathrm{Ab}$ isotypes (257). Hence, a more comprehensive insight through detailed immunoprofiling of Mtb-specific $\mathrm{Ab}$ responses during disease progression and resolution is essential, not only for TB diagnosis, but also potentially for therapeutic monitoring, and the identification of correlates of protection and markers of disease.

As B-cells and Abs significantly add to the repertoire of effector responses against $\mathrm{TB}$, these two immune components could represent interesting targets for vaccination. However, due to highly heterogenous $\mathrm{Ab}$ responses during natural $\mathrm{TB}$ infection and disease (258), it might be required to employ strategic vaccine design and specific delivery routes to effectively induce protective rather than enhancing Abs. Mucosal vaccination routes may be more likely to induce protective Mtb specific IgA, however, possibly also other protective vaccines may induce similar mucosal responses, but they have not yet been rigorously assessed. Live vaccines or selected adjuvants may skew strong $\mathrm{Ab}$ responses and influence $\mathrm{Ab}$ isotype and/or Fc glycosylation profiles $(259,260)$. Adjuvants characterized by low inflammatory and reactogenic profiles that could be safely administered through the mucosal route may be promising candidates (261).

While the discovery of BCG and antibiotics has been ground-breaking in the prevention and treatment of ATB, major knowledge gaps remain regarding better prevention and treatment of Mtb in both children and adults. Novel hostdirected therapeutic and vaccine development efforts will need to go beyond harnessing and improving only cellular immune responses, and should likely also engage the broad range of B-cell and $\mathrm{Ab}$ effector functions. As a next step, new tools that probe specificity, affinity, isotype, subclass, function and glycosylation of Abs should be developed. All accumulated evidence so far warrants detailed monitoring of B-cells and Abs in future vaccine efficacy studies, not only as correlates of protection, but also as potential contributors to protection. Since Abs are highly diverse, and this diversity relates to their functional tenures, it is important to not only assess their levels and titers, but also to dissect their functional contribution to mycobacterial inhibition and killing. Even though B-cells and Abs may not be fully sufficient on their own, they clearly can contribute to the total effector response and thereby provide novel and important targets for future studies and interventions against Mtb and other intracellular pathogens.

\section{AUTHOR CONTRIBUTIONS}

WR, TO, and SJ drafted the original manuscript outline, composed the initial draft and corrected the manuscript to its final version. All authors contributed to the article and approved the submitted version.

\section{FUNDING}

Work in the laboratory of the contributors would not have been possible without external funding. Therefore, we acknowledge EC HORIZON2020 SMA-TB (Grant No. 847762), The Netherlands Organization for Scientific Research (NWOTOP Grant No. 91214038), the National Institute of Allergy And Infectious Diseases of the National Institutes of Health under Award Number R21AI127133 and R01AI141315 for support of our work. The content is solely the responsibility of the authors and does not necessarily represent the official views of the National Institutes of Health or any funder.

\section{ACKNOWLEDGMENTS}

We would like to acknowledge Dr. Edward Knol, Utrecht University, Utrecht, The Netherlands for valuable advice during writing of this manuscript. 


\section{REFERENCES}

1. Cardona P. The progress of therapeutic vaccination with regard to tuberculosis. Front Microbiol. (2016) 7:1536. doi: 10.3389/fmicb.2016.01536

2. World Health Organization. Global Tuberculosis Report 2019. Geneva. (2019). Available online at: https://apps.who.int/iris/bitstream/handle/ 10665/329368/9789241565714-eng.pdf?ua=1 (accessed December 1, 2020).

3. Paulson T. Epidemiology: a mortal foe. Nature. (2013) 502:S23. doi: $10.1038 / 502 S 2 a$

4. Kawahara JY, Irvine EB, Alter G. A case for antibodies as mechanistic correlates of immunity in tuberculosis. Front Immunol. (2019) 10:996. doi: 10.3389/fimmu.2019.00996

5. de Martino M, Lodi L, Galli L, Chiappini E. Immune response to Mycobacterium tuberculosis: a narrative review. Front Pediatr. (2019) 7:350. doi: 10.3389/fped.2019.00350

6. Achkar JM, Casadevall A. Antibody-mediated immunity against tuberculosis: implications for vaccine development. Cell Host Microbe. (2013) 13:250-62. doi: 10.1016/j.chom.2013.02.009

7. Kozakiewicz L, Phuah J, Flynn J, Chan J. The role of B cells and humoral immunity in Mycobacterium tuberculosis infection. Adv Exp Med Biol. (2013) 783:225-50. doi: 10.1007/978-1-4614-6111-1_12

8. Joosten SA, Fletcher HA, Ottenhoff TH. A helicopter perspective on TB biomarkers: pathway and process based analysis of gene expression data provides new insight into TB pathogenesis. PLoS ONE. (2013) 8:73230. doi: 10.1371/journal.pone.0073230

9. Fine PE. Variation in protection by BCG: implications of and for heterologous immunity. Lancet. (1995) 346:133945. doi: 10.1016/S0140-6736(95)92348-9

10. Zak DE, Penn-Nicholson A, Scriba TJ, Thompson E, Suliman $\mathrm{S}$, Amon LM, et al. A blood RNA signature for tuberculosis disease risk: a prospective cohort study. Lancet. (2016) 387:231222. doi: 10.1016/S0140-6736(15)01316-1

11. Petruccioli E, Scriba TJ, Petrone L, Hatherill M, Cirillo DM, Joosten SA, et al. Correlates of tuberculosis risk: predictive biomarkers for progression to active tuberculosis. Eur Respir J. (2016) 48:1751-63. doi: 10.1183/13993003.01012-2016

12. Anderson ST, Kaforou M, Brent AJ, Wright VJ, Banwell CM, Chagaluka G, et al. Diagnosis of childhood tuberculosis and host RNA expression in Africa. N Engl J Med. (2014) 370:1712-23. doi: 10.1056/NEJMoa1303657

13. Kaforou M, Wright VJ, Oni T, French N, Anderson ST, Bangani N, et al. Detection of tuberculosis in HIV-infected and-uninfected African adults using whole blood RNA expression signatures: a case-control study. PLoS Med. (2013) 10:e1001538. doi: 10.1371/journal.pmed.1001538

14. Ottenhoff TH, Dass RH, Yang N, Zhang MM, Wong HE, Sahiratmadja $\mathrm{E}$, et al. Genome-wide expression profiling identifies type 1 interferon response pathways in active tuberculosis. PLoS ONE. (2012) 7:e45839. doi: 10.1371/journal.pone.0045839

15. Berry MP, Graham CM, McNab FW, Xu Z, Bloch SA, Oni T, et al. An interferon-inducible neutrophil-driven blood transcriptional signature in human tuberculosis. Nature. (2010) 466:973-7. doi: 10.1038/nature09247

16. Corrêa RdS, Rodrigues LS, Pereira LHL, Nogueira OC, Leung J, Sousa MdS, et al. Neutrophil CD64 expression levels in IGRA-positive individuals distinguish latent tuberculosis from active disease. Mem Inst Oswaldo Cruz. (2019) 114:e180579. doi: 10.1590/0074-02760180579

17. Sutherland J, Loxton A, Haks M, Kassa D, Ambrose L, Lee J, et al. Differential gene expression of activating $\mathrm{Fc} \gamma$ receptor classifies active tuberculosis regardless of human immunodeficiency virus status or ethnicity. Clin Microbiol Infect. (2014) 20:O230-8. doi: 10.1111/1469-0691.12383

18. Cliff JM, Lee J, Constantinou N, Cho J, Clark TG, Ronacher K, et al. Distinct phases of blood gene expression pattern through tuberculosis treatment reflect modulation of the humoral immune response. J Infect Dis. (2013) 207:18-29. doi: 10.1093/infdis/jis499

19. Joosten S, Goeman J, Sutherland J, Opmeer L, De Boer K, Jacobsen M, et al. Identification of biomarkers for tuberculosis disease using a novel dual-color RT-MLPA assay. Genes Immun. (2012) 13:71-82. doi: 10.1038/gene.2011.64

20. Maertzdorf J, Repsilber D, Parida SK, Stanley K, Roberts T, Black G, et al. Human gene expression profiles of susceptibility and resistance in tuberculosis. Genes Immun. (2011) 12:15-22. doi: 10.1038/gene.2010.51
21. Maertzdorf J, Ota M, Repsilber D, Mollenkopf HJ, Weiner J, Hill PC, et al. Functional correlations of pathogenesis-driven gene expression signatures in tuberculosis. PLoS ONE. (2011) 6:e26938. doi: 10.1371/journal.pone.0026938

22. Jacobsen M, Repsilber D, Gutschmidt A, Neher A, Feldmann K, Mollenkopf $\mathrm{HJ}$, et al. Candidate biomarkers for discrimination between infection and disease caused by Mycobacterium tuberculosis. J Mol Med (Berl). (2007) 85:613-21. doi: 10.1007/s00109-007-0157-6

23. Lubbers R, Sutherland JS, Goletti D, De Paus RA, Van Moorsel CH, Veltkamp $\mathrm{M}$, et al. Complement component $\mathrm{Clq}$ as serum biomarker to detect active tuberculosis. Front immunol. (2018) 9:2427. doi: 10.3389/fimmu.2018.02427

24. Esmail H, Lai RP, Lesosky M, Wilkinson KA, Graham CM, Horswell S, et al. Complement pathway gene activation and rising circulating immune complexes characterize early disease in HIV-associated tuberculosis. Proc Natl Acad Sci USA. (2018) 115:E964-73. doi: 10.1073/pnas.1711853115

25. Cai Y, Yang Q, Tang Y, Zhang M, Liu H, Zhang G, et al. Increased complement $\mathrm{Clq}$ level marks active disease in human tuberculosis. PLoS ONE. (2014) 9:e92340. doi: 10.1371/journal.pone.0092340

26. Schrijver B, Dijkstra DJ, Borggreven NV, La Distia Nora R, Huijser E, Versnel $\mathrm{MA}$, et al. Inverse correlation between serum complement component $\mathrm{C} 1 \mathrm{q}$ levels and whole blood type-1 interferon signature in active tuberculosis and QuantiFERON-positive uveitis: implications for diagnosis. Clin Transl Immunol. (2020) 9:e1196. doi: 10.1002/cti2.1196

27. Correia-Neves M, Fröberg G, Korshun L, Viegas S, Vaz P, Ramanlal N, et al. Biomarkers for tuberculosis: the case for lipoarabinomannan. ERJ Open Res. (2019) 5:00115-2018. doi: 10.1183/23120541.00115-2018

28. Steigler P, Verrall AJ, Kirman JR. Beyond memory T cells: mechanisms of protective immunity to tuberculosis infection. Immunol Cell Biol. (2019) 97:647-55. doi: 10.1111/imcb.12278

29. Achkar JM, Prados-Rosales R. Updates on antibody functions in Mycobacterium tuberculosis infection and their relevance for developing a vaccine against tuberculosis. Curr Opin Immunol. (2018) 53:30-7. doi: 10.1016/j.coi.2018.04.004

30. Jacobs AJ, Mongkolsapaya J, Screaton GR, McShane H, Wilkinson RJ. Antibodies and tuberculosis. Tuberculosis. (2016) 101:102-13. doi: 10.1016/j.tube.2016.08.001

31. Achkar JM, Chan J, Casadevall A. B cells and antibodies in the defense against Mycobacterium tuberculosis infection. Immunol Rev. (2015) 264:16781. doi: 10.1111/imr.12276

32. Cooper AM. Cell-mediated immune responses in tuberculosis. Annu Rev Immunol. (2009) 27:393422. doi: 10.1146/annurev.immunol.021908.132703

33. Lin PL, Flynn JL. CD8 T cells and Mycobacterium tuberculosis infection. Semin Immunopathol. (2015) 37:239-49. doi: 10.1007/s00281-015-0490-8

34. Ottenhoff $\mathrm{T}$. The knowns and unknowns of the immunopathogenesis of tuberculosis. Int $J$ Tuberc Lung Dis. (2012) 16:142432. doi: $10.5588 /$ ijtld.12.0479

35. North RJ, Jung Y. Immunity to tuberculosis. Annu Rev Immunol. (2004) 22:599-623. doi: 10.1146/annurev.immunol.22.012703.104635

36. Casadevall A. Antibody-based vaccine strategies against intracellular pathogens. Curr Opin Immunol. (2018) 53:7480. doi: 10.1016/j.coi.2018.04.011

37. Chan J, Mehta S, Bharrhan S, Chen Y, Achkar JM, Casadevall A, et al. The role of B cells and humoral immunity in Mycobacterium tuberculosis infection. Semin Immunol. (2014). 26:588-600. doi: 10.1016/j.smim.2014.10.005

38. Acosta A, Lopez Y, Nor NM, Pando RH, Alvarez N, Sarmiento ME, et al. The role of antibodies in the defense against tuberculosis. Tuberculosis. (2013) 86:191-7. doi: $10.5772 / 53950$

39. Casadevall A. Antibody-mediated immunity against intracellular pathogens: two-dimensional thinking comes full circle. Infect Immun. (2003) 71:42254228. doi: 10.1128/IAI.71.8.4225-4228.2003

40. Janeway CA, Capra JD, Travers P, Walport M. Immunobiology: The Immune System in Health and Disease. New York, NY: Garland Science. (1999). p. 884.

41. Moore BB, Moore TA, Toews GB. Role of T- and Blymphocytes in pulmonary host defences. Eur Respir J. (2001) 18:846-56. doi: 10.1183/09031936.01.00229001

42. Lu LL, Suscovich TJ, Fortune SM, Alter G. Beyond binding: antibody effector functions in infectious diseases. Nat Rev Immunol. (2018) 18:4661. doi: $10.1038 /$ nri.2017.106 
43. Li H, Javid B. Antibodies and tuberculosis: finally coming of age? Nat Rev Immunol. (2018) 18:591-6. doi: 10.1038/s41577-018-0028-0

44. Yang X, Brunham RC. Gene knockout B cell-deficient mice demonstrate that B cells play an important role in the initiation of $\mathrm{T}$ cell responses to Chlamydia trachomatis (mouse pneumonitis) lung infection. J Immunol. (1998) 161:1439-46.

45. Su H, Feilzer K, Caldwell HD, Morrison RP. Chlamydia trachomatis genital tract infection of antibody-deficient gene knockout mice. Infect Immun. (1997) 65:1993-9. doi: 10.1128/IAI.65.6.1993-1999.1997

46. Nanton MR, Way SS, Shlomchik MJ, McSorley SJ. Cutting edge: B cells are essential for protective immunity against Salmonella independent of antibody secretion. J Immunol. (2012) 189:5503-5507. doi: 10.4049/jimmunol.1201413

47. Lin FYC, Ho VA, Khiem HB, Trach DD, Bay PV, Thanh TC, et al. The efficacy of a Salmonella typhi Vi conjugate vaccine in two-to-five-year-old children. N Engl J Med. (2001) 344:1263-9. doi: 10.1056/NEJM200104263441701

48. Mastroeni P, Simmons C, Fowler R, Hormaeche CE, Dougan G. Igh-6(/-) (B-cell-deficient) mice fail to mount solid acquired resistance to oral challenge with virulent Salmonella enterica serovar typhimurium and show impaired Th1 T-cell responses to Salmonella antigens. Infect Immun. (2000) 68:46-53. doi: 10.1128/IAI.68.1.46-53.2000

49. Li JS, Winslow GM. Survival, replication, and antibody susceptibility of Ehrlichia chaffeensis outside of host cells. Infect Immun. (2003) 71:422937. doi: 10.1128/IAI.71.8.4229-4237.2003

50. Woelbing F, Kostka SL, Moelle K, Belkaid Y, Sunderkoetter C, Verbeek S, et al. Uptake of Leishmania major by dendritic cells is mediated by $\mathrm{Fc \gamma}$ receptors and facilitates acquisition of protective immunity. J Exp Med. (2006) 203:177-88. doi: 10.1084/jem.20052288

51. Gibson-Corley KN, Boggiatto PM, Bockenstedt MM, Petersen CA, Waldschmidt TJ, Jones DE. Promotion of a functional B cell germinal center response after Leishmania species co-infection is associated with lesion resolution. Am J Path. (2012) 180:2009-17. doi: 10.1016/j.ajpath.2012.01.012

52. Rodriguez-Pinto D, Saravia NG, McMahon-Pratt D. CD4 T cell activation by B cells in human Leishmania (Viannia) infection. BMC Infect Dis. (2014) 14:108. doi: 10.1186/1471-2334-14-108

53. Casadevall A, Pirofski L. Insights into mechanisms of antibody-mediated immunity from studies with Cryptococcus neoformans. Curr Mol Med. (2005) 5:421-33. doi: 10.2174/1566524054022567

54. Szymczak WA, Davis MJ, Lundy SK, Dufaud C, Olszewski M, Pirofski LA. X-linked immunodeficient mice exhibit enhanced susceptibility to Cryptococcus neoformans infection. mBio. (2013) 4:e00265-13. doi: 10.1128/mBio.00265-13

55. Zhang G, Peng Y, Schoenlaub L, Elliott A, Mitchell W, Zhang Y. Formalininactivated Coxiella burnetii phase I vaccine-induced protection depends on B cells to produce protective IgM and IgG. Infect Immun. (2013) 81:211222. doi: 10.1128/IAI.00297-13

56. Bermejo DA, Jackson SW, Gorosito-Serran M, Acosta-Rodriguez EV, Amezcua-Vesely MC, Sather BD, et al. Trypanosoma cruzi trans-sialidase initiates a program independent of the transcription factors RORgammat and Ahr that leads to IL-17 production by activated B cells. Nat Immunol. (2013) 14:514-22. doi: 10.1038/ni.2569

57. Culkin SJ, Rhinehart-Jones T, Elkins KL. A novel role for B cells in early protective immunity to an intracellular pathogen, Francisella tularensis strain LVS. J Immunol. (1997) 158:3277-84.

58. Langhorne J, Cross C, Seixas E, Li C, von der Weid T. A role for B cells in the development of $\mathrm{T}$ cell helper function in a malaria infection in mice. Proc Natl Acad Sci USA. (1998) 95:1730-4. doi: 10.1073/pnas.95.4.1730

59. Tran AC, Kim M, Reljic R. Emerging themes for the role of antibodies in tuberculosis. Immune Netw. (2019) 19:e24. doi: 10.4110/in.2019.19.e24

60. Loxton AG. Bcells and their regulatory functions during tuberculosis: latency and active disease. Mol Immunol. (2019) 111:145-51. doi: 10.1016/j.molimm.2019.04.012

61. Dyatlov AV, Apt AS, Linge IA. B lymphocytes in anti-mycobacterial immune responses: pathogenesis or protection? Tuberculosis. (2019) 114:18. doi: 10.1016/j.tube.2018.10.011

62. Rao M, Valentini D, Poiret T, Dodoo E, Parida S, Zumla A, et al. B in TB: B cells as mediators of clinically relevant immune responses in tuberculosis. Clin Infect Dis. (2015) 61:S225-34. doi: 10.1093/cid/civ614
63. Abebe F, Bjune G. The protective role of antibody responses during Mycobacterium tuberculosis infection. Clin Exp Immunol. (2009) 157:23543. doi: 10.1111/j.1365-2249.2009.03967.x

64. Glatman-Freedman A. The role of antibody-mediated immunity in defense against Mycobacterium tuberculosis: advances toward a novel vaccine strategy. Tuberculosis. (2006) 86:191-7. doi: 10.1016/j.tube.2006.01.008

65. Glatman-Freedman A, Casadevall A. Serum therapy for tuberculosis revisited: reappraisal of the role of antibody-mediated immunity against Mycobacterium tuberculosis. Clin Microbiol Rev. (1998) 11:514-32. doi: 10.1128/CMR.11.3.514

66. Khera AK, Afkhami S, Lai R, Jeyanathan M, Zganiacz A, Mandur T, et al. Role of B Cells in Mucosal Vaccine-Induced Protective CD8+ T Cell Immunity against Pulmonary Tuberculosis. J Immunol. (2015) 195:29007. doi: 10.4049/jimmunol.1500981

67. Kozakiewicz L, Chen Y, Xu J, Wang Y, Dunussi-Joannopoulos K, Ou Q, et al. B cells regulate neutrophilia during Mycobacterium tuberculosis infection and BCG vaccination by modulating the interleukin-17 response. PLoS Pathog. (2013) 9:e1003472. doi: 10.1371/journal.ppat.1003472

68. Torrado E, Fountain JJ, Robinson RT, Martino CA, Pearl JE, Rangel-Moreno J, et al. Differential and site specific impact of B cells in the protective immune response to Mycobacterium tuberculosis in the mouse. PLoS ONE. (2013) 8:e61681. doi: 10.1371/journal.pone.0061681

69. Maglione PJ, Xu J, Chan J. B cells moderate inflammatory progression and enhance bacterial containment upon pulmonary challenge with Mycobacterium tuberculosis. J Immunol. (2007) 178:7222-34. doi: 10.4049/jimmunol.178.11.7222

70. Turner J, Frank A, Brooks J, Gonzalez-Juarrero M, Orme I. The progression of chronic tuberculosis in the mouse does not require the participation of B lymphocytes or interleukin-4. Exp Gerontol. (2001) 36:537-45. doi: 10.1016/S0531-5565(00)00257-6

71. Bosio CM, Gardner D, Elkins KL. Infection of B cell-deficient mice with CDC 1551, a clinical isolate of Mycobacterium tuberculosis: delay in dissemination and development of lung pathology. J Immunol. (2000) 164:6417-25. doi: 10.4049/jimmunol.164.12.6417

72. Johnson C, Cooper A, Frank A, Bonorino C, Wysoki L, Orme I. Mycobacterium tuberculosis aerogenic rechallenge infections in B cell-deficient mice. Tuber Lung Dis. (1997) 78:257-61. doi: 10.1016/S0962-8479(97)90006-X

73. Vordermeier H, Venkataprasad N, Harris D, Ivanyi J. Increase of tuberculous infection in the organs of B cell-deficient mice. Clin Exp Immunol. (1996) 106:312-6. doi: 10.1046/j.1365-2249.1996.d01-845.x

74. Phuah J, Wong EA, Gideon HP, Maiello P, Coleman MT, Hendricks MR, et al. Effects of B cell depletion on early Mycobacterium tuberculosis infection in cynomolgus macaques. Infect Immun. (2016) 84:130111. doi: 10.1128/IAI.00083-16

75. Casadevall A, Scharff MD. Return to the past: the case for antibodybased therapies in infectious diseases. Clin Infect Dis. (1995) 21:15061. doi: 10.1093/clinids/21.1.150

76. Li H, Wang XX, Wang B, Fu L, Liu G, Lu Y, et al. Latently and uninfected healthcare workers exposed to TB make protective antibodies against Mycobacterium tuberculosis. Proc Natl Acad Sci USA. (2017) 114:50238. doi: 10.1073/pnas.1611776114

77. Guirado E, Amat I, Gil O, Díaz J, Arcos V, Caceres N, et al. Passive serum therapy with polyclonal antibodies against Mycobacterium tuberculosis protects against post-chemotherapy relapse of tuberculosis infection in SCID mice. Microb Infect. (2006) 8:1252-9. doi: 10.1016/j.micinf.2005. 12.004

78. Roy E, Stavropoulos E, Brennan J, Coade S, Grigorieva E, Walker B, et al. Therapeutic efficacy of high-dose intravenous immunoglobulin in Mycobacterium tuberculosis infection in mice. Infect Immun. (2005) 73:6101-9. doi: 10.1128/IAI.73.9.6101-6109.2005

79. Glatman-Freedman A, Martin JM, Riska PF, Bloom BR, Casadevall A. Monoclonal antibodies to surface antigens of Mycobacterium tuberculosis and their use in a modified enzyme-linked immunosorbent spot assay for detection of mycobacteria. J Clin Microbiol. (1996) 34:2795-802. doi: 10.1128/JCM.34.11.2795-2802.1996

80. Teitelbaum R, Glatman-Freedman A, Chen B, Robbins JB, Unanue E, Casadevall A, et al. A mAb recognizing a surface antigen of Mycobacterium 
tuberculosis enhances host survival. Proc Natl Acad Sci USA. (1998) 95:15688-93. doi: 10.1073/pnas.95.26.15688

81. Tran AC, Diogo GR, Paul MJ, Copland A, Hart P, Mehta N, et al. Mucosal therapy of multi-drug resistant tuberculosis with $\operatorname{IgA}$ and interferon- $\gamma$. Front Immunol. (2020) 11:582833. doi: 10.3389/fimmu.2020.582833

82. Zimmermann $\mathrm{N}$, Thormann V, Hu B, Köhler A, Imai-Matsushima A, Locht $\mathrm{C}$, et al. Human isotype-dependent inhibitory antibody responses against Mycobacterium tuberculosis. EMBO Mol Med. (2016) 8:132539. doi: $10.15252 / \mathrm{emmm} .201606330$

83. Balu S, Reljic R, Lewis MJ, Pleass RJ, McIntosh R, van Kooten C, et al. A novel human IgA monoclonal antibody protects against tuberculosis. J Immunol. (2011) 186:3113-9. doi: 10.4049/jimmunol.1003189

84. Buccheri S, Reljic R, Caccamo N, Meraviglia S, Ivanyi J, Salerno A, et al. Prevention of the post-chemotherapy relapse of tuberculous infection by combined immunotherapy. Tuberculosis. (2009) 89:914. doi: 10.1016/j.tube.2008.09.001

85. López Y, Yero D, Falero-Diaz G, Olivares N, Sarmiento ME, Sifontes $\mathrm{S}$, et al. Induction of a protective response with an IgA monoclonal antibody against Mycobacterium tuberculosis $16 \mathrm{kDa}$ protein in a model of progressive pulmonary infection. Int J Med Microbiol. (2009) 299:44752. doi: 10.1016/j.ijmm.2008.10.007

86. Buccheri S, Reljic R, Caccamo N, Ivanyi J, Singh M, Salerno A, et al. IL4 depletion enhances host resistance and passive IgA protection against tuberculosis infection in BALB/c mice. Eur J Immunol. (2007) 37:72937. doi: 10.1002/eji.200636764

87. Reljic R, Clark S, Williams A, Falero-Diaz G, Singh M, Challacombe S, et al. Intranasal IFN $\gamma$ extends passive IgA antibody protection of mice against Mycobacterium tuberculosis lung infection. Clin Exp Immunol. (2006) 143:467-73. doi: 10.1111/j.1365-2249.2006.03012.x

88. Williams A, Reljic R, Naylor I, Clark SO, Falero-Diaz G, Singh M, et al. Passive protection with immunoglobulin A antibodies against tuberculous early infection of the lungs. Immunology. (2004) 111:32833. doi: 10.1111/j.1365-2567.2004.01809.x

89. Hamasur B, Haile M, Pawlowski A, Schröder U, Källenius G, Svenson S. A mycobacterial lipoarabinomannan specific monoclonal antibody and its $\mathrm{F}$ (ab') 2 fragment prolong survival of mice infected with Mycobacterium tuberculosis. Clin Exp Immunol. (2004) 138:30-8. doi: 10.1111/j.1365-2249.2004.02593.x

90. Chambers MA, Gavier-Widen D, Glyn Hewinson R. Antibody bound to the surface antigen MPB83 of Mycobacterium bovis enhances survival against high dose and low dose challenge. FEMS Immunol Med Microbiol. (2004) 41:93-100. doi: 10.1016/j.femsim.2004.01.004

91. Pethe K, Alonso S, Biet F, Delogu G, Brennan MJ, Locht C, et al. The heparinbinding haemagglutinin of $\mathrm{M}$. tuberculosis is required for extrapulmonary dissemination. Nature. (2001) 412:190-4. doi: 10.1038/35084083

92. Chen XF, Wang WF, Zhang YD, Zhao W, Wu J, Chen TX. Clinical characteristics and genetic profiles of 174 patients with X-linked agammaglobulinemia: report from Shanghai, China (2000-2015). Medicine. (2016) 95:e4544. doi: 10.1097/MD.0000000000004544

93. Dogru D, Kiper N, Özçelik U, Yalçin E, Tezcan I. Tuberculosis in children with congenital immunodeficiency syndromes. Tuberk Toraks. (2010) 58:5963.

94. Alkadi A, Alduaiji N, Alrehaily A. Risk of tuberculosis reactivation with rituximab therapy. Int J Health Sci. (2017) 11:41-4.

95. Kimby E. Tolerability and safety of rituximab (MabThera). Cancer Treat Rev. (2005) 31:456-473. doi: 10.1016/j.ctrv.2005.05.007

96. de L. Costello A, Kumar A, Narayan V, Akbar M, Ahmed S, AbouZeid C, et al. Does antibody to mycobacterial antigens, including lipoarabinomannan, limit dissemination in childhood tuberculosis? Trans $R$ Soc Trop Med Hyg. (1992) 86:686-92. doi: 10.1016/0035-9203(92) 90192-F

97. Donald PR, Marais BJ FABarry, Clifton,E.,3rd, Barry CE,3rd. Age and the epidemiology and pathogenesis of tuberculosis. Lancet. (2010) 375:18524. doi: 10.1016/S0140-6736(10)60580-6

98. Fairchok MP, Rouse JH, Morris SL. Age-dependent humoral responses of children to mycobacterial antigens. Clin Diagn Lab Immunol. (1995) 2:4437 doi: 10.1128/CDLI.2.4.443-447.1995
99. Bothamley G, Udani P, Rudd R, Festenstein F, Ivanyi J. Humoral response to defined epitopes of tubercle bacilli in adult pulmonary and child tuberculosis. Eur J Clin Microbiol Infect Dis. (1988) 7:639-45. doi: 10.1007/BF01964242

100. Logan E, Luabeya AKK, Mulenga H, Mrdjen D, Ontong C, Cunningham $\mathrm{AF}$, et al. Elevated $\operatorname{IgG}$ responses in infants are associated with reduced prevalence of Mycobacterium tuberculosis infection. Front Immunol. (2018) 9:1529. doi: 10.3389/fimmu.2018.01529

101. Fletcher HA, Snowden MA, Landry B, Rida W, Satti I, Harris SA, et al. Tcell activation is an immune correlate of risk in BCG vaccinated infants. Nat Commun. (2016) 7:11290. doi: 10.1038/ncomms11290

102. Ziegenbalg A, Prados-Rosales R, Jenny-Avital ER, Kim RS, Casadevall A, Achkar JM. Immunogenicity of mycobacterial vesicles in humans: identification of a new tuberculosis antibody biomarker. Tuberculosis. (2013) 93:448-55. doi: 10.1016/j.tube.2013.03.001

103. Gupta S, Bhatia R, Datta K. Serological diagnosis of childhood tuberculosis by estimation of mycobacterial antigen 60 -specific immunoglobulins in the serum. Tuber Lung Dis. (1997) 78:21-7. doi: 10.1016/S0962-8479(97)90012-5

104. Bothamley GH. Serological diagnosis of tuberculosis. Eur Respir J Suppl. (1995) 20:676s-88s.

105. Sada D E, Ferguson LE, Daniel TM. An ELISA for the serodiagnosis of tuberculosis using a 30,000-Da native antigen of Mycobacterium tuberculosis. J Infect Dis. (1990) 162:928-31. doi: 10.1093/infdis/162.4.928

106. Slight SR, Rangel-Moreno J, Gopal R, Lin Y, Fallert Junecko BA, Mehra $\mathrm{S}$, et al. CXCR5 $(+) \mathrm{T}$ helper cells mediate protective immunity against tuberculosis. J Clin Invest. (2013) 123:712-26. doi: 10.1172/JCI65728

107. Kondratieva E, Logunova N, Majorov K, Averbakh M, Apt A. Host genetics in granuloma formation: human-like lung pathology in mice with reciprocal genetic susceptibility to M. tuberculosis and M. avium. PLoS ONE. (2010) 5:e10515. doi: 10.1371/journal.pone.0010515

108. Khader SA, Rangel-Moreno J, Fountain JJ, Martino CA, Reiley WW, Pearl JE, et al. In a murine tuberculosis model, the absence of homeostatic chemokines delays granuloma formation and protective immunity. J Immunol. (2009) 183:8004-14. doi: 10.4049/jimmunol.0901937

109. Kahnert A, Höpken UE, Stein M, Bandermann S, Lipp M, Kaufmann SH. Mycobacterium tuberculosis triggers formation of lymphoid structure in murine lungs. J Infect Dis. (2007) 195:46-54. doi: 10.1086/508894

110. Ulrichs T, Kosmiadi GA, Jörg S, Pradl L, Titukhina M, Mishenko V, et al. Differential organization of the local immune response in patients with active cavitary tuberculosis or with nonprogressive tuberculoma. J Infect Dis. (2005) 192:89-97. doi: 10.1086/430621

111. Gonzalez-Juarrero M, Turner OC, Turner J, Marietta P, Brooks JV, Orme IM. Temporal and spatial arrangement of lymphocytes within lung granulomas induced by aerosol infection with Mycobacterium tuberculosis. Infect Immun. (2001) 69:1722-8. doi: 10.1128/IAI.69.3.1722-1728.2001

112. Phuah JY, Mattila JT, Lin PL, Flynn JL. Activated B cells in the granulomas of nonhuman primates infected with Mycobacterium tuberculosis. Am J Pathol. (2012) 181:508-14. doi: 10.1016/j.ajpath.2012.05.009

113. Tsai MC, Chakravarty S, Zhu G, Xu J, Tanaka K, Koch C, et al. Characterization of the tuberculous granuloma in murine and human lungs: cellular composition and relative tissue oxygen tension. Cell Microbiol. (2006) 8:218-32. doi: 10.1111/j.1462-5822.2005.00612.x

114. Ulrichs T, Kosmiadi GA, Trusov V, Jörg S, Pradl L, Titukhina M, et al. Human tuberculous granulomas induce peripheral lymphoid follicle-like structures to orchestrate local host defence in the lung. J Pathol. (2004) 204:217-28. doi: 10.1002/path.1628

115. Choreño-Parra JA, Bobba S, Rangel-Moreno J, Ahmed M, Mehra S, Rosa B, et al. Mycobacterium tuberculosis HN878 infection induces human-Like B-cell follicles in mice. J Infect Dis. (2020) 221:163646. doi: 10.1093/infdis/jiz663

116. Joosten SA, van Meijgaarden KE, Del Nonno F, Baiocchini A, Petrone L, Vanini $\mathrm{V}$, et al. Patients with tuberculosis have a dysfunctional circulating B-cell compartment, which normalizes following successful treatment. PLoS Pathog. (2016) 12:e1005687. doi: 10.1371/journal.ppat.1005687

117. Marin ND, Dunlap MD, Kaushal D, Khader SA. Friend or foe: the protective and pathological roles of inducible bronchus-associated lymphoid tissue in pulmonary diseases. J Immunol. (2019) 202:251926. doi: 10.4049/jimmunol.1801135 
118. Pitzalis C, Jones GW, Bombardieri M, Jones SA. Ectopic lymphoid-like structures in infection, cancer and autoimmunity. Nat Rev Immunol. (2014) 14:447-62. doi: 10.1038/nri3700

119. Aloisi F, Pujol-Borrell R. Lymphoid neogenesis in chronic inflammatory diseases. Nat Rev Immunol. (2006) 6:205-17. doi: 10.1038/nri1786

120. Kondratieva T, Linge I, Kondratieva E, Dyatlov A, Drutskaya M, Zvartsev $\mathrm{R}$, et al. Formation of compact aggregates of B-lymphocytes in lung tissue during mycobacterial infection in mice depends on TNF production by these cells and is not an element of the host's immunological protection. Biochemistry. (2014) 79:1358-62. doi: 10.1134/S0006297914120098

121. Zhang M, Wang Z, Graner MW, Yang L, Liao M, Yang Q, et al. B cell infiltration is associated with the increased IL-17 and IL-22 expression in the lungs of patients with tuberculosis. Cell Immunol. (2011) 270:21723. doi: 10.1016/j.cellimm.2011.05.009

122. Dunlap MD, Prince OA, Rangel-Moreno J, Thomas KA, Scordo JM, Torrelles JB, et al. Formation of lung inducible bronchus associated lymphoid tissue is regulated by Mycobacterium tuberculosis expressed determinants. Front Immunol. (2020) 11:1325. doi: 10.3389/fimmu.2020.01325

123. Corominas M, Cardona V, Gonzalez L, Cayla J, Rufi G, Mestre M, et al. Blymphocytes and co-stimulatory molecules in Mycobacterium tuberculosis infection. Int J Tuberc Lung Dis. (2004) 8:98-105.

124. Chowdhury RR, Vallania F, Yang Q, Angel CJL, Darboe F, PennNicholson A, et al. A multi-cohort study of the immune factors associated with M. tuberculosis infection outcomes. Nature. (2018) 560:6448. doi: 10.1038/s41586-018-0439-x

125. Hernandez J, Velazquez C, Valenzuela O, Robles-Zepeda R, Ruiz-Bustos E, Navarro M, et al. Low number of peripheral blood B lymphocytes in patients with pulmonary tuberculosis. Immunol Invest. (2010) 39:197205. doi: $10.3109 / 08820130903586346$

126. Wu Y, Zhang S, Peng W, Li K, Li K, Jiang J, et al. Changes in lymphocyte subsets in the peripheral blood of patients with active pulmonary tuberculosis. J Int Med Res. (2009) 37:1742-9. doi: 10.1177/147323000903700610

127. Barcelos W, Martins-Filho OA, Guimarães, Tânia Mara Pinto Dabés, Oliveira MHP, Spíndola-de-Miranda S, Carvalho BN, et al. Peripheral blood mononuclear cells immunophenotyping in pulmonary tuberculosis patients before and after treatment. Microbiol Immunol. (2006) 50:597605. doi: 10.1111/j.1348-0421.2006.tb03834.x

128. Linge I, Dyatlov A, Kondratieva E, Avdienko V, Apt A, Kondratieva T. B-lymphocytes forming follicle-like structures in the lung tissue of tuberculosis-infected mice: dynamics, phenotypes and functional activity. Tuberculosis. (2017) 102:16-23. doi: 10.1016/j.tube.2016. 11.005

129. Du Plessis WJ, Keyser A, Walzl G, Loxton AG. Phenotypic analysis of peripheral B cell populations during Mycobacterium tuberculosis infection and disease. J Inflamm. (2016) 13:23. doi: 10.1186/s12950-016-0133-4

130. Lundy SK, Klinker MW, Fox DA. Killer B lymphocytes and their fas ligand positive exosomes as inducers of immune tolerance. Front Immunol. (2015) 6:122. doi: 10.3389/fimmu.2015.00122

131. Abreu MT, Carvalheiro H, Rodrigues-Sousa T, Domingos A, Segorbe-Luis A, Rodrigues-Santos P, et al. Alterations in the peripheral blood B cell subpopulations of multidrug-resistant tuberculosis patients. Clin Exp Med. (2014) 14:423-9. doi: 10.1007/s10238-013-0258-1

132. Zhang $M$, Zeng G, Yang Q, Zhang J, Zhu X, Chen Q, et al. Antituberculosis treatment enhances the production of IL-22 through reducing the frequencies of regulatory B cell. Tuberculosis (Edinb). (2014) 94:23844. doi: 10.1016/j.tube.2013.12.003

133. Lundy SK. Killer B lymphocytes: the evidence and the potential. Inflamm Res. (2009) 58:345-57. doi: 10.1007/s00011-009-0014-X

134. Lyashchenko KP, Vordermeier HM, Waters WR. Memory B cells and tuberculosis. Vet Immunol Immunopathol. (2020) 221:110016. doi: 10.1016/j.vetimm.2020.110016

135. Moir S, Ho J, Malaspina A, Wang W, DiPoto AC, O'Shea MA, et al. Evidence for HIV-associated B cell exhaustion in a dysfunctional memory B cell compartment in HIV-infected viremic individuals. J Exp Med. (2008) 205:1797-805. doi: 10.1084/jem.20072683

136. Moore DK, Leisching GR, Snyders CI, Gutschmidt A, Van Rensburg IC, Loxton AG, et al. Immunoglobulin profile and B-cell frequencies are altered with changes in the cellular micro-environment independent of the stimulation conditions. BioRxiv. (2019). doi: 10.1101/818153

137. Zhang M, Zheng X, Zhang J, Zhu Y, Zhu X, Liu H, et al. CD19 CD1d CD5 B cell frequencies are increased in patients with tuberculosis and suppress Th17 responses. Cell Immunol. (2012) 274:89-97. doi: 10.1016/j.cellimm.2012.01.007

138. van Rensburg IC, Loxton AG. Killer (FASL regulatory) B cells are present during latent $\mathrm{TB}$ and are induced by BCG stimulation in participants with and without latent tuberculosis. Tuberculosis. (2018) 108:114-7. doi: 10.1016/j.tube.2017.11.010

139. van Rensburg IC, Kleynhans L, Keyser A, Walzl G, Loxton AG. Bcells with a FasL expressing regulatory phenotype are induced following successful anti-tuberculosis treatment. Immunity Inflam Dis. (2017) 5:5767. doi: 10.1002/iid3.140

140. van Rensburg IC, Wagman C, Stanley K, Beltran C, Ronacher K, Walzl G, et al. Successful TB treatment induces B-cells expressing FASL and IL5RA mRNA. Oncotarget. (2017) 8:2037-43. doi: 10.18632/oncotarget.12184

141. Dubois Cauwelaert N, Baldwin SL, Orr MT, Desbien AL, Gage E, Hofmeyer $\mathrm{KA}$, et al. Antigen presentation by $\mathrm{B}$ cells guides programing of memory CD4 T-cell responses to a TLR4-agonist containing vaccine in mice. Eur J Immunol. (2016) 46:2719-29. doi: 10.1002/eji.201646399

142. Lund FE, Randall TD. Effector and regulatory B cells: modulators of CD4 T cell immunity. Nat Rev Immunol. (2010) 10:236-47. doi: 10.1038/nri2729

143. Bouaziz JD, Yanaba K, Venturi GM, Wang Y, Tisch RM, Poe JC, et al. Therapeutic B cell depletion impairs adaptive and autoreactive CD4+ T cell activation in mice. Proc Natl Acad Sci USA. (2007) 104:2087883. doi: 10.1073/pnas.0709205105

144. Andersen CS, Dietrich J, Agger EM, Lycke NY, Lovgren K, Andersen P. The combined CTA1-DD/ISCOMs vector is an effective intranasal adjuvant for boosting prior Mycobacterium bovis BCG immunity to Mycobacterium tuberculosis. Infect Immun. (2007) 75:408-16. doi: 10.1128/IAI.01290-06

145. Helgeby A, Robson NC, Donachie AM, Beackock-Sharp H, Lovgren $\mathrm{K}$, Schon K, et al. The combined CTA1-DD/ISCOM adjuvant vector promotes priming of mucosal and systemic immunity to incorporated antigens by specific targeting of B cells. J Immunol. (2006) 176:3697706. doi: 10.4049/jimmunol.176.6.3697

146. Hon H, Oran A, Brocker T, Jacob J. B lymphocytes participate in crosspresentation of antigen following gene gun vaccination. J Immunol. (2005) 174:5233-242. doi: 10.4049/jimmunol.174.9.5233

147. du Plessis WJ, Kleynhans L, du Plessis N, Stanley K, Malherbe ST, Maasdorp E, et al. The functional response of $\mathrm{B}$ cells to antigenic stimulation: a preliminary report of latent tuberculosis. PLoS One. (2016) 11:e0152710. doi: 10.1371/journal.pone.0152710

148. Shen H, Chen ZW. The crucial roles of Th17-related cytokines/signal pathways in M. tuberculosis infection. Cell Molecular Immunol. (2018) 15:216-225. doi: 10.1038/cmi.2017.128

149. Stephen-Victor E, Sharma VK, Das M, Karnam A, Saha C, Lecerf M, et al. IL-1 $\beta$, but not programed death-1 and programed death ligand pathway, is critical for the human Th17 response to Mycobacterium tuberculosis. Front Immunol. (2016) 7:465. doi: 10.3389/fimmu.2016.00465

150. da Silva MV, Tiburcio MGS, Machado JR, Silva DAA, Rodrigues DBR, Rodrigues V, et al. Complexity and controversies over the cytokine profiles of $\mathrm{T}$ helper cell subpopulations in tuberculosis. J Immunol Res. (2015) 2015:639107. doi: 10.1155/2015/639107

151. Leal IS, Smedegard B, Andersen P, Appelberg R. Interleukin-6 and interleukin-12 participate in induction of a type 1 protective T-cell response during vaccination with a tuberculosis subunit vaccine. Infect Immun. (1999) 67:5747-54. doi: 10.1128/IAI.67.11.5747-5754.1999

152. Zhang X, Kiapour N, Kapoor S, Khan T, Thamilarasan M, Tao Y, et al. IL-11 Induces encephalitogenic Th17 cells in multiple sclerosis and experimental autoimmune encephalomyelitis. J Immunol. (2019) 203:114250. doi: 10.4049/jimmunol.1900311

153. Zhang $\mathrm{X}$, Tao Y, Chopra M, Dujmovic-Basuroski I, Jin J, Tang $\mathrm{Y}$, et al. IL-11 Induces Th17 cell responses in patients with early relapsing-remitting multiple sclerosis. J Immunol. (2015) 194:513949. doi: 10.4049/jimmunol.1401680

154. Olsen A, Chen Y, Ji Q, Zhu G, De Silva AD, Vilcheze C, et al. Targeting Mycobacterium tuberculosis tumor necrosis factor alpha-downregulating 
genes for the development of antituberculous vaccines. mBio. (2016) 7:e01023-15. doi: 10.1128/mBio.01023-15

155. Cavalcanti YVN, Brelaz MCA, Neves, Juliana Kelle de Andrade Lemoine, Ferraz JC, Pereira VRA. Role of TNF-alpha, IFN-gamma, and IL-10 in the development of pulmonary tuberculosis. Pulmonary Med. (2012) 2012:745483. doi: 10.1155/2012/745483

156. Lin PL, Plessner HL, Voitenok NN, Flynn JL. Tumor necrosis factor and tuberculosis. J Investig Dermatol Symp Proc. (2007) 12:22-5. doi: 10.1038/sj.jidsymp.5650027

157. Flynn JL, Chan J. What's good for the host is good for the bug. Trends Microbiol. (2005) 13:98-102. doi: 10.1016/j.tim.2005.01.005

158. Moreira-Teixeira L, Redford PS, Stavropoulos E, Ghilardi N, Maynard CL, Weaver CT, et al. T cell-derived IL-10 impairs host resistance to Mycobacterium tuberculosis Infection. J Immunol. (2017) 199:61323. doi: 10.4049/jimmunol.1601340

159. Abdalla AE, Lambert N, Duan X, Xie J. Interleukin-10 family and tuberculosis: an old story renewed. Int J Biol Sci. (2016) 12:71017. doi: 10.7150/ijbs.13881

160. Redford P, Murray P, O'garra A. The role of IL-10 in immune regulation during M. tuberculosis infection. Mucosal immunol. (2011) 4:26170. doi: $10.1038 / \mathrm{mi} .2011 .7$

161. Higgins DM, Sanchez-Campillo J, Rosas-Taraco AG, Lee EJ, Orme IM, Gonzalez-Juarrero M. Lack of IL-10 alters inflammatory and immune responses during pulmonary Mycobacterium tuberculosis infection. Tuberculosis). (2009) 89:149-57. doi: 10.1016/j.tube.2009.01.001

162. Kimuda SG, Andia-Biraro I, Sebina I, Egesa M, Nalwoga A, Smith $\mathrm{SG}$, et al. Mycobacterium tuberculosis infection is associated with increased B cell responses to unrelated pathogens. Sci Rep. (2020) 10:14324. doi: 10.1038/s41598-020-71044-4

163. Lu LL, Smith MT, Krystle K, Luedemann C, Suscovich TJ, Grace PS, et al. IFN- $\gamma$-independent immune markers of Mycobacterium tuberculosis exposure. Nat Med. (2019) 25:977-87. doi: 10.1038/s41591-019-0441-3

164. Mave V, Chandrasekaran P, Chavan A, Shivakumar, Shri Vijay Bala Yogendra, Danasekaran K, Paradkar M, et al. Infection free "resisters" among household contacts of adult pulmonary tuberculosis. PLoS ONE. (2019) 14:e0218034. doi: 10.1371/journal.pone.0218034

165. Seshadri C, Sedaghat N, Campo M, Peterson G, Wells RD, Olson GS, et al. Transcriptional networks are associated with resistance to Mycobacterium tuberculosis infection. PLoS ONE. (2017) 12:e0175844. doi: 10.1371/journal.pone.0175844

166. Hanifa Y, Grant A, Lewis J, Corbett E, Fielding K, Churchyard G. Prevalence of latent tuberculosis infection among gold miners in South Africa. Int $J$ Tuberc Lung Dis. (2009) 13:39-46.

167. Kaipilyawar V, Salgame P. Infection resisters: targets of new research for uncovering natural protective immunity against Mycobacterium tuberculosis. F1000Research. (2019) 8:F1000 Faculty Rev-1698. doi: 10.12688/f1000research.19805.1

168. Cobat A, Gallant CJ, Simkin L, Black GF, Stanley K, Hughes J, et al. Two loci control tuberculin skin test reactivity in an area hyperendemic for tuberculosis. J Exp Med. (2009) 206:2583-91. doi: 10.1084/jem.20090892

169. Chin ST, Ignatius J, Suraiya S, Tye GJ, Sarmiento ME, Acosta A, et al. Comparative study of IgA VH 3 gene usage in healthy TST- and TST population exposed to tuberculosis: deep sequencing analysis. Immunology. (2015) 144:302-11. doi: 10.1111/imm.12372

170. Bothamley GH, Beck JS, Potts RC, Grange JM, Kardjito T, Ivanyi J. Specificity of antibodies and tuberculin response after occupational exposure to tuberculosis. J Infect Dis. (1992) 166:182-6. doi: 10.1093/infdis/166.1.182

171. Encinales L, Zuñiga J, Granados-Montiel J, Yunis M, Granados J, Almeciga I, et al. Humoral immunity in tuberculin skin test anergy and its role in high-risk persons exposed to active tuberculosis. Mol Immunol. (2010) 47:1066-73. doi: 10.1016/j.molimm.2009.11.005

172. Feris EJ, Encinales L, Awad C, Stern JN, Tabansky I, Jiménez-Alvarez L, et al. High levels of anti-tuberculin (IgG) antibodies correlate with the blocking of T-cell proliferation in individuals with high exposure to Mycobacterium tuberculosis. Int J Infect Dis. (2016) 43:21-4. doi: 10.1016/j.ijid.2015. 12.004

173. Kimuda SG, Andia-Biraro I, Egesa M, Bagaya BS, Raynes JG, Levin $J$, et al. Use of QuantiFERON@-TB Gold in-tube culture supernatants for measurement of antibody responses. PLoS ONE. (2017) 12:e0188396. doi: 10.1371/journal.pone.0188396

174. Raja A, Baughman RP, Daniel TM. The detection by immunoassay of antibody to mycobacterial antigens and mycobacterial antigens in bronchoalveolar lavage fluid from patients with tuberculosis and control subjects. Chest. (1988) 94:133-7. doi: 10.1378/chest.94.1.133

175. Demkow U, Białas-Chromiec B, Filewska M, Sobiecka M, Kuś J, Szturmowicz $M$, et al. Humoral immune response against mycobacterial antigens in bronchoalveolar fluid from tuberculosis patients. J Physiol Pharmacol. (2005) 56(Suppl. 4):79-84.

176. Feng L, Li L, Liu Y, Qiao D, Li Q, Fu X, et al. B lymphocytes that migrate to tuberculous pleural fluid via the SDF-1/CXCR4 axis actively respond to antigens specific for Mycobacterium tuberculosis. Eur J Immunol. (2011) 41:3261-9. doi: 10.1002/eji.201141625

177. Grosset J. Mycobacterium tuberculosis in the extracellular compartment: an underestimated adversary. Antimicrob Agents Chemother. (2003) 47:8336. doi: 10.1128/AAC.47.3.833-836.2003

178. Achkar JM, Chan J, Casadevall A. Role of B cells and antibodies in acquired immunity against Mycobacterium tuberculosis. Cold Spring Harb Perspect Med. (2014) 5:a018432. doi: 10.1101/cshperspect.a018432

179. Schlesinger LS, Hull SR, Kaufman TM. Binding of the terminal mannosyl units of lipoarabinomannan from a virulent strain of Mycobacterium tuberculosis to human macrophages. The J Immunol. (1994) 152:4070-9.

180. Chen T, Blanc C, Liu Y, Ishida E, Singer S, Xu J, et al. Capsular glycan recognition provides antibody-mediated immunity against tuberculosis. $J$ Clin Invest. (2020) 130:1808-22. doi: 10.1172/JCI128459

181. Chen T, Blanc C, Eder AZ, Prados-Rosales R, Souza ACO, Kim RS, et al. Association of human antibodies to arabinomannan with enhanced mycobacterial opsonophagocytosis and intracellular growth reduction. $J$ Infect Dis. (2016) 214:300-10. doi: 10.1093/infdis/jiw141

182. Manivannan S, Rao VN, Ramanathan V. Role of complement activation and antibody in the interaction between Mycobacterium tuberculosis and human macrophages. Indian J Exp Biol. (2012) 50:542-50.

183. Carroll MV, Lack N, Sim E, Krarup A, Sim RB. Multiple routes of complement activation by Mycobacterium bovis BCG. Mol Immunol. (2009) 46:3367-78. doi: 10.1016/j.molimm.2009.07.015

184. Hetland G, Wiker HG, Høgåsen K, Hamasur B, Svenson SB, Harboe M. Involvement of antilipoarabinomannan antibodies in classical complement activation in tuberculosis. Clin Diagn Lab Immunol. (1998) 5:2118. doi: 10.1128/CDLI.5.2.211-218.1998

185. Lu LL, Chung AW, Rosebrock TR, Ghebremichael M, Yu WH, Grace PS, et al. A functional role for antibodies in tuberculosis. Cell. (2016) 167:43343.e14. doi: 10.1016/j.cell.2016.08.072

186. McEwan WA, Tam JC, Watkinson RE, Bidgood SR, Mallery DL, James LC. Intracellular antibody-bound pathogens stimulate immune signaling via the Fc receptor TRIM21. Nat Immunol. (2013) 14:327-36. doi: 10.1038/ni.2548

187. Geijtenbeek TB, Gringhuis SI. An inside job for antibodies: tagging pathogens for intracellular sensing. Nat Immunol. (2013) 14:309-11. doi: 10.1038/ni.2574

188. Maglione PJ, Xu J, Casadevall A, Chan J. Fc gamma receptors regulate immune activation and susceptibility during Mycobacterium tuberculosis infection. J Immunol. (2008) 180:3329-38. doi: 10.4049/jimmunol.180.5.3329

189. de Valliere S, Abate G, Blazevic A, Heuertz RM, Hoft DF. Enhancement of innate and cell-mediated immunity by antimycobacterial antibodies. Infect Immun. (2005) 73:6711-20. doi: 10.1128/IAI.73.10.6711-6720.2005

190. Casadevall A, Pirofski L. A new synthesis for antibody-mediated immunity. Nat Immunol. (2012) 13:21-8. doi: 10.1038/ni.2184

191. Clynes R. Protective mechanisms of IVIG. Curr Opin Immunol. (2007) 19:646-51. doi: 10.1016/j.coi.2007.09.004

192. Casadevall A, Pirofski L. A reappraisal of humoral immunity based on mechanisms of antibody-mediated protection against intracellular pathogens. Adv Immunol. (2006) 91:144. doi: 10.1016/S0065-2776(06)91001-3

193. Casadevall A, Pirofski L. The damage-response framework of microbial pathogenesis. Nat Rev Microbiol. (2003) 1:17-24. doi: 10.1038/nrmicro732

194. Kumar SK, Singh P, Sinha S. Naturally produced opsonizing antibodies restrict the survival of Mycobacterium tuberculosis in human 
macrophages by augmenting phagosome maturation. Open Biol. (2015) 5:150171. doi: 10.1098/rsob.150171

195. Fratti RA, Chua J, Vergne I, Deretic V. Mycobacterium tuberculosis glycosylated phosphatidylinositol causes phagosome maturation arrest. Proc Nati Acad Sci USA. (2003) 100:5437-42. doi: 10.1073/pnas.0737613100

196. Malik ZA, Denning GM, Kusner DJ. Inhibition of $\mathrm{Ca}(2+)$ signaling by Mycobacterium tuberculosis is associated with reduced phagosome-lysosome fusion and increased survival within human macrophages. J Exp Med. (2000) 191:287-302. doi: 10.1084/jem.191.2.287

197. Armstrong JA, Hart PD. Phagosome-lysosome interactions in cultured macrophages infected with virulent tubercle bacilli. Reversal of the usual nonfusion pattern and observations on bacterial survival. J Exp Med. (1975) 142:1-16. doi: 10.1084/jem.142.1.1

198. Joller N, Weber SS, Muller AJ, Sporri R, Selchow P, Sander P, et al. Antibodies protect against intracellular bacteria by Fc receptormediated lysosomal targeting. Proc Natl Acad Sci USA. (2010) 107:204416. doi: 10.1073/pnas.1013827107

199. Suga M, Tanaka F, Muranaka H, Nishikawa H, Ando M. Effect of antibacterial antibody on bactericidal activities of superoxide and lysosomal enzyme from alveolar macrophages in rabbits. Respirology. (1996) 1:12732. doi: 10.1111/j.1440-1843.1996.tb00021.x

200. Kang PB, Azad AK, Torrelles JB, Kaufman TM, Beharka A, Tibesar E, et al. The human macrophage mannose receptor directs Mycobacterium tuberculosis lipoarabinomannan-mediated phagosome biogenesis. J Exp Med. (2005) 202:987-99. doi: 10.1084/jem.20051239

201. Torrelles JB, Azad AK, Schlesinger LS. Fine discrimination in the recognition of individual species of phosphatidyl-myo-inositol mannosides from Mycobacterium tuberculosis by C-type lectin pattern recognition receptors. J Immunol. (2006) 177:1805-16. doi: 10.4049/jimmunol.177.3.1805

202. Joosten SA, van Meijgaarden KE, Arend SM, Prins C, Oftung F, Korsvold $\mathrm{GE}$, et al. Mycobacterial growth inhibition is associated with trained innate immunity. J Clin Invest. (2018) 128:1837-51. doi: 10.1172/JCI97508

203. Forrester MA, Wassall HJ, Hall LS, Cao H, Wilson HM, Barker $\mathrm{RN}$, et al. Similarities and differences in surface receptor expression by THP-1 monocytes and differentiated macrophages polarized using seven different conditioning regimens. Cell Immunol. (2018) 332:5876. doi: 10.1016/j.cellimm.2018.07.008

204. Fleit HB, Kobasiuk CD. The human monocyte-like cell line THP-1 expresses Fc $\gamma$ RI and Fc $\gamma$ RII. J Leukoc Biol. (1991) 49:556-65. doi: 10.1002/jlb.49.6.556

205. Kedzierska K, Ellery P, Mak J, Lewin SR, Crowe SM, Jaworowski A. HIV1 down-modulates gamma signaling chain of $F_{c}$ gamma $R$ in human macrophages: a possible mechanism for inhibition of phagocytosis. $J$ Immunol. (2002) 168:2895-903. doi: 10.4049/jimmunol.168.6.2895

206. Daëron M. Fc receptor biology. Annu Rev Immunol. (1997) 15:20334. doi: 10.1146/annurev.immunol.15.1.203

207. Foltz C, Napolitano A, Khan R, Clough B, Hirst EM, Frickel E. TRIM21 is critical for survival of Toxoplasma gondii infection and localises to GBP-positive parasite vacuoles. Sci Rep. (2017) 7:5209. doi: 10.1038/s41598-017-05487-7

208. Rakebrandt N, Lentes S, Neumann H, James LC, Neumann-Staubitz P. Antibody-and TRIM21-dependent intracellular restriction of Salmonella enterica. Path Dis. (2014) 72:131-7. doi: 10.1111/2049-632X.12192

209. Bussi C, Gutierrez MG. Mycobacterium tuberculosis infection of host cells in space and time. FEMS Microbiol Rev. (2019) 43:341-61. doi: 10.1093/femsre/fuz006

210. McLean MR, Lu L, Kent SJ, Chung AW. An inflammatory story: antibodies in Mycobacterium tuberculosis co-morbidities. Front Immunol. (2019) 10:2846. doi: 10.3389/fimmu.2019.02846

211. Belay M, Legesse M, Mihret A, Ottenhoff TH, Franken KL, Bjune G, et al. IFN- $\gamma$ and IgA against non-methylated heparin-binding hemagglutinin as markers of protective immunity and latent tuberculosis: results of a longitudinal study from an endemic setting. J Infect. (2016) 72:189200. doi: 10.1016/j.jinf.2015.09.040

212. Dijkman K, Sombroek CC, Vervenne RA, Hofman SO, Boot C, Remarque EJ, et al. Prevention of tuberculosis infection and disease by local BCG in repeatedly exposed rhesus macaques. Nat Med. (2019) 25:25562. doi: 10.1038/s41591-018-0319-9
213. Darrah PA, Zeppa JJ, Maiello P, Hackney JA, Wadsworth MH, Hughes TK, et al. Prevention of tuberculosis in macaques after intravenous BCG immunization. Nature. (2020) 577:95-102. doi: 10.1038/s41586-019-1817-8

214. Alvarez N, Otero O, Camacho F, Borrero R, Tirado Y, Puig A, et al. Passive administration of purified secretory IgA from human colostrum induces protection against Mycobacterium tuberculosis in a murine model of progressive pulmonary infection. BMC Immunol. (2013) 14(Suppl. 1):S3. doi: 10.1186/1471-2172-14-S1-S3

215. Rodríguez A, Tjärnlund A, Ivanji J, Singh M, García I, Williams A, et al. Role of $\operatorname{IgA}$ in the defense against respiratory infections: IgA deficient mice exhibited increased susceptibility to intranasal infection with Mycobacterium bovis BCG. Vaccine. (2005) 23:2565-72. doi: 10.1016/j.vaccine.2004.11.032

216. Tjärnlund A, Rodríguez A, Cardona P, Guirado E, Ivanyi J, Singh M, et al. Polymeric IgR knockout mice are more susceptible to mycobacterial infections in the respiratory tract than wild-type mice. Int Immunol. (2006) 18:807-16. doi: 10.1093/intimm/dxl017

217. Mantis NJ, Rol N, Corthésy B. Secretory IgA’s complex roles in immunity and mucosal homeostasis in the gut. Mucosal immunol. (2011) 4:60311. doi: $10.1038 / \mathrm{mi} .2011 .41$

218. Corthësy B. Secretory immunoglobulin A: well beyond immune exclusion at mucosal surfaces. Immunopharmacol Immunotoxicol. (2009) 31:1749. doi: 10.1080/08923970802438441

219. Reljic R, Williams A, Ivanyi J. Mucosal immunotherapy of tuberculosis: is there a value in passive IgA? Tuberculosis. (2006) 86:179-90. doi: 10.1016/j.tube.2006.01.011

220. Reljic R, Ivanyi J. A case for passive immunoprophylaxis against tuberculosis. Lancet Infect Dis. (2006) 6:813-18. doi: 10.1016/S1473-3099(06)70658-2

221. Reljic R, Crawford C, Challacombe S, Ivanyi J. Mouse IgA inhibits cell growth by stimulating tumor necrosis factor- $\alpha$ production and apoptosis of macrophage cell lines. Int Immunol. (2004) 16:607-14. doi: 10.1093/intimm/dxh070

222. Jennewein MF, Alter G. The immunoregulatory roles of antibody glycosylation. Trends Immunol. (2017) 38:35872. doi: 10.1016/j.it.2017.02.004

223. Irvine EB, Alter G. Understanding the role of antibody glycosylation through the lens of severe viral and bacterial diseases. Glycobiology. (2020) 30:24153. doi: $10.1093 /$ glycob/cwaa018

224. Vadrevu SK, Trbojevic-Akmacic I, Kossenkov AV, Colomb F, Giron LB, Anzurez A, et al. Frontline science: plasma and immunoglobulin G galactosylation associate with HIV persistence during antiretroviral therapy. J Leukoc Biol. (2018) 104:461-71. doi: 10.1002/JLB.3HI1217-500R

225. Moore JS, Wu X, Kulhavy R, Tomana M, Novak J, Moldoveanu $\mathrm{Z}$, et al. Increased levels of galactose-deficient IgG in sera of HIV-1-infected individuals. AIDS. (2005) 19:3819. doi: 10.1097/01.aids.0000161767.21405.68

226. Alter G, Ottenhoff TH, Joosten SA. Antibody glycosylation in inflammation, disease and vaccination. Semin Immunol. (2018) 39:102-10. doi: 10.1016/j.smim.2018.05.003

227. Pilkington C, Yeung E, Isenberg D, Lefvert A, Rook G. Agalactosyl IgG and antibody specificity in rheumatoid arthritis, tuberculosis, systemic lupus erythematosus and myasthenia gravis. Autoimmunity. (1995) 22:10711. doi: $10.3109 / 08916939508995306$

228. Parekh R, Isenberg D, Rook G, Roitt I, Dwek R, Rademacher T. A comparative analysis of disease-associated changes in the galactosylation of serum IgG. J Autoimmun. (1989) 2:101-14. doi: 10.1016/0896-8411(89)90148-0

229. Rademacher TW, Parekh RB, Dwek RA, Isenberg D, Rook G, Axford JS, et al. The role of IgG glycoforms in the pathogenesis of rheumatoid arthritis. Springer Sem Immunopath. (1988) 10:231-49. doi: 10.1007/BF01 857227

230. Malhotra R, Wormald MR, Rudd PM, Fischer PB, Dwek RA, Sim RB. Glycosylation changes of IgG associated with rheumatooid arthritis can activate complement via the mannose-binding protein. Nat Med. (1995) 1:237-43. doi: 10.1038/nm0395-237

231. Seeling M, Brückner C, Nimmerjahn F. Differential antibody glycosylation in autoimmunity: sweet biomarker or modulator of disease activity? Nat Rev Rheumatol. (2017) 13:621-30. doi: 10.1038/nrrheum.2017.146 
232. Lu LL, Das J, Grace PS, Fortune SM, Restrepo BI, Alter G. Antibody FC glycosylation discriminates between latent and active tuberculosis. J Infect Dis. (2020) 222:2093-102. doi: 10.1093/infdis/jiz643

233. Ottenhoff TH, Kaufmann SH. Vaccines against tuberculosis: where are we and where do we need to go? PLoS Pathog. (2012) 8:e1002607. doi: 10.1371/journal.ppat.1002607

234. Sebina I, Cliff JM, Smith SG, Nogaro S, Webb EL, Riley EM, et al. Long-lived memory B-cell responses following BCG vaccination. PLoS ONE. (2012) 7:e51381. doi: 10.1371/journal.pone.0051381

235. Aguilo N, Uranga S, Mata E, Tarancon R, Gómez AB, Marinova $\mathrm{D}$, et al. Respiratory immunization with a whole cell inactivated vaccine induces functional mucosal immunoglobulins against tuberculosis in mice and non-human primates. Front Microbiol. (2020) 11:1339. doi: 10.3389/fmicb.2020.01339

236. Shin HJ, Franco LH, Nair VR, Collins AC, Shiloh MU. A baculovirus-conjugated mimotope vaccine targeting Mycobacterium tuberculosis lipoarabinomannan. PLoS ONE. (2017) 12:e0185945. doi: 10.1371/journal.pone.0185945

237. Wang L, Feng S, An L, Gu G, Guo Z. Synthetic and immunological studies of mycobacterial lipoarabinomannan oligosaccharides and their protein conjugates. J Org Chem. (2015) 80:10060-75. doi: 10.1021/acs.joc.5b01686

238. Glatman-Freedman A, Casadevall A, Dai Z, Jacobs WR,Jr, Li A, Morris SL, et al. Antigenic evidence of prevalence and diversity of Mycobacterium tuberculosis arabinomannan. J Clin Microbiol. (2004) 42:3225-31. doi: 10.1128/JCM.42.7.3225-3231.2004

239. Hamasur B, Haile M, Pawlowski A, Schröder U, Williams A, Hatch G, et al. Mycobacterium tuberculosis arabinomannanprotein conjugates protect against tuberculosis. Vaccine. (2003) 21:4081-93. doi: 10.1016/S0264-410X(03)00274-3

240. Hamasur B, Källenius G, Svenson SB. Synthesis and immunologic characterisation of Mycobacterium tuberculosis lipoarabinomannan specific oligosaccharide-protein conjugates. Vaccine. (1999) 17:2853-61. doi: 10.1016/S0264-410X(99)00124-3

241. Prados-Rosales R, Carreño L, Cheng T, Blanc C, Weinrick B, Malek A, et al. Enhanced control of Mycobacterium tuberculosis extrapulmonary dissemination in mice by an arabinomannan-protein conjugate vaccine. PLoS pathogens. (2017) 13:e1006250. doi: 10.1371/journal.ppat. 1006250

242. Tameris MD, Hatherill M, Landry BS, Scriba TJ, Snowden MA, Lockhart $\mathrm{S}$, et al. Safety and efficacy of MVA85A, a new tuberculosis vaccine, in infants previously vaccinated with BCG: a randomised, placebo-controlled phase 2b trial. Lancet. (2013) 381:1021-8. doi: 10.1016/S0140-6736(13) 60177-4

243. Van Der Meeren O, Hatherill M, Nduba V, Wilkinson RJ, Muyoyeta M, Van Brakel E, et al. Phase 2b controlled trial of M72/AS01E vaccine to prevent tuberculosis. N Engl J Med. (2018) 379:162134. doi: 10.1056/NEJMoa1803484

244. Penn-Nicholson A, Geldenhuys H, Burny W, van der Most R, Day CL, Jongert E, et al. Safety and immunogenicity of candidate vaccine M72/AS01E in adolescents in a TB endemic setting. Vaccine. (2015) 33:402534. doi: 10.1016/j.vaccine.2015.05.088

245. Tait DR, Hatherill M, Van Der Meeren O, Ginsberg AM, Van Brakel E, Salaun $\mathrm{B}$, et al. Final analysis of a trial of M72/AS01E vaccine to prevent tuberculosis. N Engl J Med. (2019) 381:2429-39. doi: 10.1056/NEJMoa1909953

246. Zimmermann P, Donath S, Perrett KP, Messina NL, Ritz N, Netea MG, et al. The influence of neonatal bacille calmette-guerin (BCG) immunisation on heterologous vaccine responses in infants. Vaccine. (2019) 37:373544. doi: 10.1016/j.vaccine.2019.03.016

247. de Bree, L Charlotte J, Koeken VA, Joosten LA, Aaby P, Benn CS, van Crevel R, et al. Non-specific effects of vaccines: current evidence and potential implications. Semin Immunol. (2018). 39:3543. doi: 10.1016/j.smim.2018.06.002
248. Jensen KJ, Larsen N, Biering-Sørensen S, Andersen A, Eriksen HB, Monteiro I, et al. Heterologous immunological effects of early BCG vaccination in lowbirth-weight infants in Guinea-Bissau: a randomized-controlled trial. J Infect Dis. (2015) 211:956-67. doi: 10.1093/infdis/jiu508

249. Kleinnijenhuis J, van Crevel R, Netea MG. Trained immunity: consequences for the heterologous effects of BCG vaccination. Trans R Soc Trop Med Hyg. (2015) 109:29-35. doi: 10.1093/trstmh/tru168

250. Giamarellos-Bourboulis EJ, Tsilika M, Moorlag S, Antonakos N, Kotsaki A, Domínguez-Andrés J, et al. Activate: randomized clinical trial of BCG vaccination against infection in the elderly. Cell. (2020) 183:31523e9. doi: 10.1016/j.cell.2020.08.051

251. Bulut O, Kilic G, Domínguez-Andrés J, Netea MG. Overcoming immune dysfunction in the elderly: trained immunity as a novel approach. Int Immunol. (2020) 32:741-53. doi: 10.1093/intimm/dxaa052

252. Divangahi $M$, Aaby $P$, Khader SA, Barreiro LB, Bekkering $S$, Chavakis $\mathrm{T}$, et al. Trained immunity, tolerance, priming and differentiation: distinct immunological processes. Nat Immunol. (2021) 22:2-6. doi: 10.1038/s41590-020-00845-6

253. Cirovic B, de Bree, L Charlotte J, Groh L, Blok BA, Chan J, van der Velden, Walter JFM, et al. BCG vaccination in humans elicits trained immunity via the hematopoietic progenitor compartment. Cell Host Microbe. (2020) 28:322-34. e5. doi: 10.1016/j.chom.2020.05.014

254. Boyaka PN. Inducing Mucosal IgA: a challenge for vaccine adjuvants and delivery systems. J Immunol. (2017) 199:916. doi: 10.4049/jimmunol.1601775

255. Kaufmann SH. Envisioning future strategies for vaccination against tuberculosis. Nat Rev Immunol. (2006) 6:699-704. doi: 10.1038/nri1920

256. Hussain R, Dawood G, Abrar N, Toossi Z, Minai A, Dojki M, et al. Selective increases in antibody isotypes and immunoglobulin $G$ subclass responses to secreted antigens in tuberculosis patients and healthy household contacts of the patients. Clin Diagn Lab Immunol. (1995) 2:72632 doi: 10.1128/CDLI.2.6.726-732.1995

257. Abebe F, Belay M, Legesse M, KLMC F, Ottenhoff TH. IgA and IgG against Mycobacterium tuberculosis Rv2031 discriminate between pulmonary tuberculosis patients, Mycobacterium tuberculosisinfected and non-infected individuals. PLoS ONE. (2018) 13:e0190989. doi: 10.1371/journal.pone.0190989

258. Kunnath-Velayudhan S, Salamon H, Wang HY, Davidow AL, Molina DM, Huynh VT, et al. Dynamic antibody responses to the Mycobacterium tuberculosis proteome. Proc Natl Acad Sci USA. (2010) 107:147038. doi: 10.1073/pnas.1009080107

259. Mahan AE, Jennewein MF, Suscovich T, Dionne K, Tedesco J, Chung AW, et al. Antigen-specific antibody glycosylation is regulated via vaccination. PLoS pathogens. (2016) 12:e1005456. doi: 10.1371/journal.ppat.1005456

260. Karagouni E, Hadjipetrou-Kourounakis L. Regulation of isotype immunoglobulin production by adjuvants in vivo. Scand J Immunol. (1990) 31:745-54. doi: 10.1111/j.1365-3083.1990.tb02826.x

261. Stewart E, Triccas JA, Petrovsky N. Adjuvant strategies for more effective tuberculosis vaccine immunity. Microorganisms. (2019) 7:255. doi: 10.3390/microorganisms 7080255

Conflict of Interest: The authors declare that the research was conducted in the absence of any commercial or financial relationships that could be construed as a potential conflict of interest.

Copyright (c) 2021 Rijnink, Ottenhoff and Joosten. This is an open-access article distributed under the terms of the Creative Commons Attribution License (CC BY). The use, distribution or reproduction in other forums is permitted, provided the original author(s) and the copyright owner(s) are credited and that the original publication in this journal is cited, in accordance with accepted academic practice. No use, distribution or reproduction is permitted which does not comply with these terms. 